INVESTIGACIÓN

https://doi.org/10.15198/seeci.2019.48.17-43

Recibido: 18/09/2018 --- Aceptado: 21/01/2019 --- Publicado: 15/03/2019

\title{
LA COSMOVISIÓN DE LA TRANSICIÓN ESPAÑOLA EN LA PELÍCULA JUANA LA LOCA.., DE VEZ EN CUANDO UN MANUAL PARA LA COMPRENSION DE LA COMEDIA HISTORICA DE LOS OCHENTA
}

\section{THE WORLDVIEW OF THE SPANISH TRANSITION IN THE MOVIE JOAN THE MAD... ONCE IN A WHILE A MANUAL FOR THE UNDERSTANDING OF THE HISTORICAL COMEDY OF THE EIGHTIES}

Antonio Rafael Fernández Paradas': Universidad de Granada. España. antonioparadas@ugr.es

Rubén Sánchez Guzmán: Ayuntamiento de Madrid. España. ruben sanguzman@hotmail.com

Investigación realizada dentro del Proyecto de Innovación Educativa de la Universidad de Málaga "Implementación de mejoras en el proceso de enseñanza-aprendizaje de las Competencias Digitales en Humanidades, Ciencias Sociales y Educación", PIE 17-020.

\section{RESUMEN}

Aunque fue uno de los grandes taquillazos cinematográficos de la época, Juana la Loca... de vez en cuando (José Ramón Larraz, 1983), recibió unas duras críticas por parte del público especializado, que veían en la cinta una penosa manera de hacer cine. Personajes, ambientación, guion, interpretaciones, etc., nada escapó a la pluma de los críticos, que se cebaron duramente con ella. Aun así, el público conectó a la perfección con ella, no en vano, la Corte de los Reyes Católicos vino a hacer suya la lejana Transición española. Mediante la siguiente investigación, queremos poner en valor esta importante aportación del cine español, como un documento que refleja a la perfección la vida política, social, cultural y artística de la Transición española, ofreciendo un compendio que permita comprender la minuciosidad e intelectualidad del guion en toda su complejidad.

PALABRAS CLAVE: Transición española - Juana la Loca... de vez en cuando comedia histórica - cine - Reyes Católicos - José Ramón Larraz - Parodia.

\footnotetext{
${ }^{1}$ Antonio Rafael Fernández Paradas: Doctor en Historia del Arte por la Universidad de Málaga. Graduado en Historia del Arte y Licenciado en Documentación por la Universidad de Granada. Máster en Peritaje y Tasación de Antigüedades y obras de arte por la Universidad de Alcalá de Henares. antonioparadas@ugr.es
} 
Fernández Paradas, A. R., y Sánchez Guzmán, R. La cosmovisión de la Transición española en la película Juana la Loca... de vez en cuando un manual para la comprensión de la

comedia histórica de los ochenta

\section{ABSTRACT}

Although it was one of the great movie blockbusters of the time, Joan the Mad... once in a while (José Ramón Larraz, 1983), received harsh criticism from the specialized public, who saw in the film a painful way of making movies. Characters, ambience, script, interpretations, etc., nothing escaped the pen of the critics, who vented their criticism on it. Even so, the public connected perfectly with it, not in vain, the Court of the Catholic Kings came to make the distant Spanish transition their own. Through the following research, we want to value this important contribution of Spanish cinema, as a document that perfectly reflects the political, social, cultural and artistic life of the Spanish Transition, offering a compendium that allows us to understand the thoroughness and intellectuality of the script in all its complexity.

KEY WORDS: Spanish Transition - Joan the Mad... once in a while - historical comedy - cinema - Catholic Kings - José Ramón Larraz - Parody.

\section{A COSMOVISÃO DA TRANSIÇÃO ESPANHOLA NO FILME JUANA LA LOCA.... DE VEZ EN CUANDO UM MANUAL PARA A COMPREENSÃO DA COMÉDIA HISTÓRICA DOS ANOS 80}

\section{RESUME}

Embora tenha sido um dos grandes êxitos cinematográficos da época, "Juana la Loca... de vez em quando" (Jose Ramon Larraz, 1983), recebeu duras críticas por parte do público especializado que viam no filme uma penosa maneira de fazer cinema. Personagens, ambientação, guião, interpretações, etc, nada escapou dos críticos, que se excederam duramente com ela. Ainda assim, o público conectou a perfeição com ela, devido a parodia feita em referência à a Transição Espanhola trasladada à corte dos Reis Católicos. Mediante a seguinte investigação, queremos ressaltar esta importante aportaçao do cinema espanhol, como um documento que reflete à perfeição a vida política, social, cultural e artística da Transição Espanhola, oferecendo um compendio que permita compreender a minuciosidade $e$ intelectualidade do guião em toda sua complexidade.

PALAVRAS ChAVE: Transição Espanhola - Juana la Loca... de vez em quando comedia histórica - cinema - Reis Católicos - Jose Ramon Larraz - Parodia.

\section{Cómo citar el artículo:}

Fernández Paradas, A. R., y Sánchez Guzmán, R. (2019). La cosmovisión de la Transición española en la película Juana la Loca... de vez en cuando un manual para la comprensión de la comedia histórica de los ochenta. [The worldview of the Spanish Transition in the movie Joan the Mad... once in a while a manual for the understanding of the historical comedy of the eighties]. Revista de Comunicación de la SEECI, 48, 17-43. doi: http://doi.org/10.15198/seeci.2019.48.17-43 . Recuperado de http://www.seeci.net/revista/index.php/seeci/article/view/556 
Fernández Paradas, A. R., y Sánchez Guzmán, R. La cosmovisión de la Transición española en la película Juana la Loca... de vez en cuando un manual para la comprensión de la

comedia histórica de los ochenta

\section{INTRODUCCIÓN}

No es España un país en el que hayamos explotado en exceso nuestra historia en el cine. Durante el franquismo se explota con frecuencia este género con fines puntualmente patrióticos y propagandísticos; los grandes personajes épicos de la historia de España, empiezan a desfilar por los cines de barrio: los Reyes Católicos, Juana la Loca, la epopeya colombina; en otras ocasiones son un simple pretexto para un melodrama histórico, ¿Dónde vas Alfonso XII? Con la muerte del general Franco (Zunzunegui, 2005) y la llegada de la Transición, se amplía la paleta de personajes, el cine se desprende de sus connotaciones políticas anteriores, apareciendo nuevos temas, en ocasiones más comprometidos (González González, 2009). Singular resulta el hecho de un subgénero que se da a principio de los ochenta (Torres, 1992), donde se profundiza en los grandes temas de la historia de España, conectado con trabajos anteriores del franquismo (Alba de América o Locura de amor) (Del Amo, 2009). La nómina no es amplia, apenas un pequeño puñado de películas que si bien disfrutaron de enorme éxito de taquilla en su momento, fueron machacadas por la crítica (Montoya et al., 2015). La primera en estrenarse en 1983, fue Cristóbal Colón de oficio descubridor, que llego a llevar al cine a más de un millón y medio de espectadores, fue seguida un año después por Juana la Loca... de vez en cuando (verdadero paradigma del efímero subgénero) y El Cid cabreador (Payán, 2007). Todas ellas, pero sobre todo el trasunto de Locura de amor de Juan de Orduña, (Juana la Loca... de vez en cuando) dirigida por José Ramón Larraz con guion de Juan José Alonso Millán, gracias a sus gags humorísticos, sumamente contemporáneos, son un sorprendente exponente de dualidad semántica. Por un lado, la propia recreación histórica de la película, caracterización de personajes, localizaciones, etc., por otro lado, los gags referentes a la España de los años ochenta. Estos los podemos encontrar de distintas formas, tanto objetos anacrónicos, como sobre todo en los diálogos del guion, de difícil comprensión para aquellas generaciones que no vivieron o están familiarizadas con la vida política, económica o social, cultural de la Transición. A tenor de lo expuesto, es esta dualidad, la que hace que a la vez, los recursos atiendan a dos épocas bien diferenciadas y separadas por siglos la una de la otra (Martínez Montalbán, 1989), (Monterder, 1993).

\section{OBJETIVOS}

El principal objetivo de la presente investigación es poner de manifiesto, con la perspectiva que dan los 35 años que han pasado desde el estreno de Juana la Loca... de vez en cuando, que las durísimas críticas que el film recibió en el momento de su estreno, tanto en su aparato interpretativo como el guion de la cinta, hoy en día cobran una dimensión totalmente diferente. Para nosotros, Juana la Loca, se nos antoja como un documento histórico de primera magnitud, cuya correcta compresión es un libro abierto sobre los modos de vida, de sentir y crear en la España de la Transición democrática. Las críticas coetáneas al estreno de la película, ya hacían hincapié a las múltiples referencias a la vida cultural, política, legislativa y doméstica de esa España que comenzaba alejarse de la apesadumbrada herencia del franquismo. Precisamente, las críticas, con carácter general, señalaban lo poco

Revista de Comunicación de la SEECI. 15 marzo 2019 /15 julio, 2019, no 48, 17-43 
Fernández Paradas, A. R., y Sánchez Guzmán, R. La cosmovisión de la Transición española en la película Juana la Loca... de vez en cuando un manual para la comprensión de la

apropiado de construir un guion en base a tales referencias. El efecto contrario, fue el impacto que provocó la película en la taquilla, superando exponencialmente el éxito de la "películas cultas" o "bien hechas" de la época.

Se da la circunstancia de que en la actualidad, un español que naciera después de Naranjito (la mascota del Mundial de Futbol de 1982 en España), y mucho menos uno que vinera al mundo después del entierro de la peseta (2000), es materialmente imposible que comprenda la película Juana la Loca... de vez en cuando, en su total plenitud, ya que los comentarios, coñas y parodias, reflejan una determinada cosmovisión del mundo, que difícilmente podrán comprender los que no la vivieron. En pleno siglo XXI, se hace necesario acudir a la semiótica (Vidales González, 2009) y a la iconografía, para poder comprender la cinta en su inmensa complejidad intelectual.

De manera específica queremos responder a los siguientes objetivos:

- Analizar todas y cada una de las referencias a la vida, social, cultural, política, económica, doméstica, tecnológica, etc., recogidas en la película.

- Identificar e interpretar estas referencias.

- Analizarlas bajo los códigos audiovisuales, comunicativos, expresivos, creativos y culturales de la época.

- Crear un corpus de conocimiento que permita a cualquier persona comprender de una manera simple, ordenada y organizada la película Juana la Loca.

\section{METODOLOGÍA}

Desde el punto de vista metodológico, se han llevado acabo cuatro procesos concatenados. En un primer momento, se ha contextualizado la película en la historiografía y en el marco teórico. Queríamos saber qué se ha dicho de la película y cómo, entre la intelectualidad científica. En segundo lugar, hemos consultado directamente, gracias a los archivos de la Filmoteca Nacional, las críticas que recibió la película en el momento de su estreno. También hemos analizado diversos datos estadísticos que nos han permitido comprender la dimensión económica y social de la cinta. En una tercera etapa hemos minutado al completo la película, incidiendo en los aspectos, económicos, culturales, científicos, sociales, tecnológicos, legislativos, judiciales, etc., que podemos encontrar (Losilla Alcalde, 1999). Aquí cabe realizar una apreciación, hemos tenido la oportunidad de consultar directamente el guion original de la película conservado entre los fondos de la Filmoteca Nacional. Para realizar el minutado de la película y extraer los comentarios objeto de análisis, lo hemos hecho directamente sobre la propia cinta, y no sobre el guion, ya que hemos podido constatar notables diferencias entre el guion y la película final. Una vez que hemos analizado el texto fílmico, hemos creado una tabla de triple entrada, donde en un orden secuencial, hemos recogido, literalmente el comentario de la película y hemos procedido a analizarlo e interpretarlo bajo los códigos visuales de la época. Es importante mencionar que también hemos incluido no solo citas textuales, sino que también hemos analizado objetos decorativos y de uso, revistas y periódicos que aparecen, instrumentos tecnológicos, como videos, etc. El corpus de conocimiento generado, nos ha permitido expandir el conocimiento que teníamos sobre la película 
Fernández Paradas, A. R., y Sánchez Guzmán, R. La cosmovisión de la Transición española en la película Juana la Loca... de vez en cuando un manual para la comprensión de la comedia histórica de los ochenta

Juana la Loca... de vez en cuando, poniendo de manifiesto su importancia en la actualidad como documento histórico.

Tabla 0. Ejemplo de la tabla realizada y de las interpretaciones de los comentarios y objetos.

\begin{tabular}{|c|l|l|}
\hline MINUTADO & \multicolumn{1}{|c|}{ TRANSCRIPCIÓN } & \multicolumn{1}{c|}{ COMENTARIO } \\
\hline \multirow{3}{*}{$2: 33$} & $\begin{array}{l}\text { Isabel la Católica (a Fernando): } \\
\text { "y que contraten al juglar Fraga, } \\
\text { para que nos cante una muñeira } \\
\text { sobre lo pernicioso del divorcio" }\end{array}$ & $\begin{array}{l}\text { Manuel Fraga (1922-2012). Ministro de } \\
\text { Franco, y fundador de Alianza Popular } \\
\text { y Partido Popular, destacó en contra de } \\
\text { laprobación de la Ley del Divorcio } \\
\text { aprobada el 7 de julio de 1981. }\end{array}$ \\
\hline
\end{tabular}

Fuente: Elaboración propia.

\section{DISCUSIÓN}

\subsection{Juana la Loca, reacciones ante una película}

Se puede considerar que la pionera en este género (una astracanada pura con personajes históricos reconocibles), fue Cristóbal Colón... de oficio descubridor (1983), producida por José Frade y dirigida por Mariano Ozores, tándem que ya había trabajado con anterioridad, en otras comedias, El liguero mágico (1980) y Brujas mágicas (1981), siguiendo la estela de Polvos mágicos (1979), primera comedia ambientada en un contexto de terror, que tuvo un extraordinario rendimiento comercial. Las bases ya estaban creadas y no se tardó en coger a los tótems de la historia de España encumbrados por el cine franquista, Alba de América (1951), Locura de amor (1948), y que sus protagonistas con verdadera desfachatez, hablaran de la política de la época, los nuevos cambios sociales, o los personajes contemporáneos, rodeados de objetos anacrónicos (Losilla Alcalde, 1999). Además de con Mariano Ozores como director, Frade contó con Juan José Alonso Millán como guionista, -autor teatral que debutó recogiendo las esencias del humor satírico y absurdo en la línea de Jardiel y Mihura y la comedia amable y comercial de Alfonso Paso- que por aquellos momentos, era uno de los guionistas más requeridos para el cine comercial (humor y destape) que triunfaba en España (casi 60 guiones en 20 años), con títulos tan populares como No desearás al vecino del quinto (1971), (Payán, 2007). Alonso Millán se convertía aquí en un verdadero titiritero que, hacia moverse a Colón, los Reyes Católicos, Torquemada o Cisneros en unas circunstancias y diálogos que los desmitificaban por completo, con constantes alusiones a la realidad española del momento (López Gandía y Pedraza, 1989). La cinta estrenada en el madrileño cine Callao el 8 de septiembre de 1982 (el mismo año que José Luis Garci se había traído el Oscar con Volver a empezar), fue como se podía esperar, acribillada por la Crítica, si bien es cierto que un poco desconcertada con esta una nueva fórmula de hacer comedia, que contaba con precedentes tanto nacionales como extranjeros (Muñoz Seca o los Monty Python). Sin embargo, la película gozó de un éxito comercial sin precedentes, con una recaudación de 1.725.384,69 Euros, y 1.412.893 de espectadores, convirtiéndose en la película española más taquillera del año, dejando noqueada a La colmena de Mario Camus, que un año 
Fernández Paradas, A. R., y Sánchez Guzmán, R. La cosmovisión de la Transición española en la película Juana la Loca... de vez en cuando un manual para la comprensión de la

comedia histórica de los ochenta

después consiguió el Oso de Oro en el Festival de Cine de Berlín. Comenta Andrés Pajares que al cruzarse con Camilo José Cela, el creador de La colmena y ganador del Nobel le recriminó que Cristóbal Colón... de oficio descubridor (1982) estuviese noqueando la adaptación cinematográfica de su obra en taquilla. "Seguro que la tuya es más divertida", le espetó Cela. https://elpais.com/elpais/2018/05/17/icon/1526574743 362895.html (Consultado el 1 de julio de 2018).

Tras el éxito cosechado por Cristóbal Colón... de oficio descubridor, su productor José Frade quiso seguir explotando el filón con Juana la Loca... de vez en cuando (1983), que se puede considerar continuación de la primera, pues la película continúa donde la otra lo deja, tras el descubrimiento de América por Colón, el aspecto visual es muy parecido, y muchos de sus personajes estaban dotados de similares características, incluso (caso de Torquemada, Cisneros y Juana la Loca) interpretados por los mismos actores. El reparto coral conto con los actores más populares del momento (José Luis Vázquez, Lola Flores, Manolo Gómez Bur, Quique Camoiras, Juanito Navarro, Beatriz Elorrieta o Jaime Morey), Frade contó, de nuevo, con un guion del citado Juan José Alonso Millán, aunque en este caso con un mayor contenido de la política del momento. La cinta fue encargada a José Ramón Larraz, quien ya había dirigido otros guiones de Alonso Millán (La momia nacional, 1981). Larraz comenzó su carrera como escritor de comic para revistas, de aquí pasó a la fotografía y luego a la cinematografía. De 1974 es su primer éxito Síntomas, que representó a Gran Bretaña en el Festival de Cannes, y ese mismo año Las hijas de Drácula, todo un icono de cine fantástico español de la década de los setenta (Fantaterror), al convertir a las vampiresas en seres llenos de sensualidad, mezclando el terror con el erotismo. De vuelta a España, en 1976 Larraz se especializaría en el cine de terror que alternaría con lo puramente erótico, con regresos puntuales a la comedía, cuya primera incursión fue Polvos Mágicos en 1979. Hasta 1994 dirigió más de 14 películas, retirándose definitivamente en 2002 con la miniserie Viento del pueblo: Miguel Hernández (2002) que narra la vida del poeta de Orihuela. Vapuleado por la crítica española desde su regreso (todo lo contrario de cómo fue tratado en Inglaterra y Estados Unidos), como el mismo Larraz reconocía, solo recibió en toda su carrera en España dos buenas críticas, una de Diego Galán y otra de Maruja Torres, y las dos por El mirón (1977), considerada por el mismo como una de sus mejores películas. Juana la Loca... de vez en cuando, no fue una excepción en las malas críticas, como veremos (García Barrientos, 2004). La película rodada durante 1983, fue estrenada el 19 de septiembre de 1983 en los cines Roxy (sala A), Windsor (Sala A) y Montera de Madrid, y un día después en Barcelona en los cines Borras y Rex. El estreno fue precedido por una amplia campaña publicitaria, que anunciaba la cinta como "Una película que le hará volverse loco durante un rato", "Doña Juana estaba loca pero no tanto", "Después de Colón viene doña Juana, de locura", "Felipe era tan hermoso como horteripop", "El más loco reinado de Castilla". Si bien y aunque los datos (espectadores y recaudación) distaban mucho de igualar a los de Cristóbal Colón, fue de nuevo secundada por los espectadores, con un total de 370.469 , y $468.283,76$ Euros de recaudación. Como en otras tantas ocasiones, el gusto de los espectadores y la Crítica no fueron por el mismo camino, esta última descuartizó la película y el guion. El crítico Raúl Carney en Cine Asesor,

Revista de Comunicación de la SEECI. 15 marzo 2019 /15 julio, 2019, nº 48, 17-43 
Fernández Paradas, A. R., y Sánchez Guzmán, R. La cosmovisión de la Transición española en la película Juana la Loca... de vez en cuando un manual para la comprensión de la comedia histórica de los ochenta

en la página informativa exclusiva para las empresas de exhibición cinematográfica, argumentaba que "Hay un cierto cine, cuyo denominador común es la chabaquenería y el mal gusto. Este film, en la línea de Mariano Ozores, promete pasar un rato divertido, pero su guion y sus diálogos son una verdadera vergüenza". Prosigue vapuleando el guion "se recurre a la ya tan manida oportunidad de hacer reír a base de la intemporalidad, mezclando la historia antigua con connotaciones sociales de la realidad española del 83. Se cita de manera estúpida a Rumasa, a políticos y demás parafernalia de todos conocida y de dominio público". Aprovecha Carney para hacer referencia al hartazgo (al menos para él), de este determinado tipo de comedias "puede ser que el público que solo quiere pasar un rato de risa en el cine, y que le importa poco la calidad fílmica, pueda divertirse, pero seguimos diciendo que ese español ya no es tan tonto y quiere productos dignos a cambio de sus 300 pts.". Termina admitiendo que, pese a todo, este tipo de cine tiene su público, calificándolo de mediano a buen rendimiento, recomendándose su programación en "círculos populares y en programación doble".

F. Marinero en Diario 16, del 24 de septiembre de 1983, tras sorprenderse del éxito de Cristóbal Colón... de oficio descubridor, habla de la fórmula del éxito que vuelve a repetirse "parodia de época con constantes referencias a la actualidad, la inclusión de números musicales y la multiplicación de gracias a cargo de un reparto de famosos". Continúa hablando de la repartición de la cinta entre dos tipos de bromas, la desmitificación de los personajes "Fernando es un marido sojuzgado que López Vázquez tanto ha representado en comedias costumbristas. Cisneros es una momia afeminada y Torquemada un puritano zascandil", y el "chiste político que de chiste solo tiene su limitación a citar a personajes públicos o hacer comparaciones con la expropiación de Rumasa". Terminando la columna, no sin cierta ironía, "eso, más otras muestras de ingenio que van desde la utilización de una calculadora electrónica a la escatología infantil, hace de Juana la Loca... de vez en cuando, no la comedia enloquecida que se pretende, sino una aburrida sucesión de los tópicos del humor reaccionario".

No menos contundente se mostró la crítica del diario $A B C$ del 21 de septiembre de 1983. Destacando las características generales de basarse "en el Anacronismo y la sal gruesa", continua arremetiendo contra el director al que califica de "especialista de porno a la inglesa", rematando que "la vulgaridad asumida acaba por convertirse en pura chabacanería", a la vez que pone el grito en el cielo, recordemos que es el $\mathrm{ABC}$, con el grito final de "Viva la República", que califica de "improcedente" además de "parecer querer dotar a lo que antecede de un significado político más que vidrioso". Días después, el 1 de octubre, la edición Sevillana de ABC, volvía a despacharse a gusto. Recogiendo los argumentos de la columna anterior, añadía que era "una astracanada con una comicidad burda que raya en lo chabacano" y concluyendo que se trataba de "un ludibrio del manubrio celtibérico", ¿alguien da más?

Más corrosivo si cabe con evidentes tintes políticos, se mostró el diario catalán AVUI, en su crítica de cine del 25 de septiembre. Tras hacer un breve repaso al director "por el título, el tipo de publicidad y el nombre de algunos intérpretes, 
Fernández Paradas, A. R., y Sánchez Guzmán, R. La cosmovisión de la Transición española en la película Juana la Loca... de vez en cuando un manual para la comprensión de la comedia histórica de los ochenta

parecía que Larraz quería depararnos un entretenimiento sobre "mariquitas", travestis y otros marginados singulares", comienza una verdadera andanada de descalificativos, "La colección de tonterías a que se dedican los personajes, la irreverencia e inconsistencia del tratamiento temático, la falta de gracia e ingenio de las alusiones al presente... no están al servicio... de una camada desmitificadora o de un análisis crítico hecha en broma, sino de una sencilla e insustancial payasada sin suelta"si bien al final apunta que verlos "disfrazados de figuras históricas e histéricas que el franquismo ha mitificado hasta el delirio, tiene cierta gracia".

Mucho más benévola fue la crítica del diario deportivo AS el 24 de septiembre, sin duda ajeno a cualquier ínfula cultural. Alabando el excelente reparto y augurando una buena trayectoria comercial, a la vez que remarcaba que, si "la principal preocupación con esta película es la de arrancar la carcajada del público, lo han conseguido plenamente".

Pero ¿qué opinaban sus actores de la película?, tenemos las palabras de Fernando el Católico, como muestra. En la biografía de José Luis López Vázquez, el mismo utiliza el término "alimentaria" (es decir le daban de comer), para referirse a Juana la Loca y otros productos similares de la época, y continúa "Hombre, ya se sabía lo que era... Pues como la de Juana la Loca u otra que también hice de Cristóbal Colón, eran películas que se hacían a conciencia porque uno, lógicamente, ya sabía lo que iba a perpetrar... eran parodias históricas malas, con humor grueso, pero lo hacíamos porque nos pagaban... estábamos deseando acabar, uno pensaba: a ver cuándo me quito esto de encima"(Lorente, 2010, p. 250). La opinión ha quedado clara.

Si bien como hemos apuntado con cifras el éxito de Juana estaba distante del disfrutado un año antes por Cristóbal Colón, no se puede negar que fue otro pelotazo económico, por lo tanto, la fórmula fue explotada hasta su agotamiento. El mismo año de 1983, otro productor, en este caso Ramiro Bermúdez de Castro, se subía a la estela con La loca historia de los tres mosqueteros, cinta para lucimiento del entonces trío humorístico Martes y 13, contando para su dirección con Mariano Ozores, con guion a la limón de Mariano y de nuevo Alonso Millán. Si bien el contenido referente a la política contemporánea quedó bastante más reducido, no así los objetos anacrónicos que pueblan la escenografía. Entre tanto, José Frade, creador del invento, volvía a la carga con una película de corte muy similar a Juana la Loca, pero ambientada en la Edad Media, El Cid cabreador (1983), dirigida por Angelino Fons, pero de nuevo con el omnipresente Alonso Millán como Guionista (Cine Español, 1983). La crítica especializada no tardó en despedazarla, pero el crítico Diego Galán en El País, del 12 de diciembre de 1983, reconocía a José Frade como el creador de esta "formula de comedia sin duda rentable", aunque el rendimiento de público y recaudación no fue el esperado (370.469 espectadores y $468.283,76$ euros) y Frade abandonó "el invento". Sin embargo, aún existió un último acto, ajeno a Frade y Alonso Millán, Cuando Almanzor perdió el tambor (1984) donde se dieron cita todos los tópicos vistos, dándose por agotado el filón. Atrás se quedaron otros proyectos surgidos en plena borrachera de éxito de Cristóbal Colón, el propio Alonso Millán confesaba al periodista José María Amilibia en las páginas del ABC, del 8 de septiembre de 1983, a punto de estrenarse Juana la Loca, su intención

Revista de Comunicación de la SEECI. 15 marzo 2019 /15 julio, 2019, no 48, 17-43 
Fernández Paradas, A. R., y Sánchez Guzmán, R. La cosmovisión de la Transición española en la película Juana la Loca... de vez en cuando un manual para la comprensión de la

de hacer toda la historia de España, en dos películas, Adiós mi España querida, como la copla de Antonio Molina (Cine para Leer, 1983).

Paralelamente a este cine comercial y popular "La Españolada" le quedaban los días contados. La llegada del partido socialista al poder en 1982, trajo consigo en nombramiento de Pilar Miró como Directora General de Cinematografía en diciembre 1982 (García Santamaría). Entre otras muchas medidas legislativas tomadas en este periodo, fue el desarrollo de la conocida "Ley Miró", cuyo principal objetivo era la producción de películas de calidad. Para tal fin se articularon distintos instrumentos, como una junta de calificación de películas, y el nunca visto hasta la fecha, la concesión de subvenciones para financiar la producción de estas películas, es decir, la junta con sus criterios de calidad, financiaba un determinado cine, dejando este fuera de ese juego, el cine comercial que hasta ese momento llenaba las salas (Utrera Macías, 2005).

A partir de este periodo, si bien el cine ganó en calidad, el descenso de cuota de pantalla del cine español bajo drásticamente de un 22,9\% en 1982 hasta un ridículo $7,5 \%$ en 1989. Entre 1982 y 1985 se produjo un cierre masivo de las salas de proyecciones, concentrándose la mayoría en los centros urbanos, que favorecía la asistencia de un público más culto, viéndose la producción de películas populares o "populacheras" sin sus tradicionales lugares de consumo (cines de barrio, o de poblaciones pequeñas, que cerraron en muchas ocasiones), y directamente expulsadas del nuevo sistema surgido (Zunzunegui, 1987).

\subsection{La historia de un país en perspectiva anacrónica. Juana la Loca... de vez en cuando: un universo ampliado}

\section{Tabla 1}

\begin{tabular}{|c|l|l|}
\hline MINUTADO & \multicolumn{1}{|c|}{ TRANSCRIPCIÓN } & \multicolumn{1}{c|}{ COMENTARIO } \\
\hline \multirow{5}{*}{$2: 33$} & $\begin{array}{l}\text { Isabel la Católica (a Fernando): } \\
\text { "Y que contraten al juglar Fraga, } \\
\text { para que nos cante una muñeira } \\
\text { sobre lo pernicioso del divorcio". }\end{array}$ & $\begin{array}{l}\text { Manuel Fraga (1922-2012) Ministro de } \\
\text { Franco, y fundador de Alianza Popular } \\
\text { y Partido Popular, destacó en contra de } \\
\text { la aprobación de la Ley del Divorcio } \\
\text { aprobada el 7 de julio de 1981. }\end{array}$ \\
\hline \multirow{5}{*}{$5: 14$} & $\begin{array}{l}\text { Torquemada (a Isabel la } \\
\text { Católica): "Estoy dejando a la } \\
\text { católica España de lo más } \\
\text { expropiada... El zángano se ha } \\
\text { cepillado a la abeja". } \\
\text { Isabel: "iAy! Torquemada no } \\
\text { entiendo nada. ¿Quién es el } \\
\text { zángano? } \\
\text { Torquemada: "Está escrito en } \\
\text { clave Majestad, a vuestro ministro } \\
\text { de finanzas lo llamo así, Fray } \\
\text { Bollero". }\end{array}$ & $\begin{array}{l}\text { El } 23 \text { de febrero de 1983, el Consejo } \\
\text { decretó la expropiación forzosa del } \\
\text { grupo Rumasa, ostentando Miguel } \\
\text { Boyer (Fray Bollero) la Cartera de } \\
\text { Economía. Un octógono con una abeja } \\
\text { en su interior era la imagen corporativa } \\
\text { del holding. }\end{array}$ \\
\hline \multirow{2}{*}{$06: 50$} & $\begin{array}{l}\text { Isabel (a Torquemada): "Colón } \\
\text { llegara pronto y con él la ayuda } \\
\text { americana". }\end{array}$ & $\begin{array}{l}\text { Tras el apoyo español a las potencias } \\
\text { del eje encabezadas por los alemanes, } \\
\text { durante la Segunda Guerra Mundial, y }\end{array}$ \\
\hline
\end{tabular}


Fernández Paradas, A. R., y Sánchez Guzmán, R. La cosmovisión de la Transición española en la película Juana la Loca... de vez en cuando un manual para la comprensión de la comedia histórica de los ochenta

\begin{tabular}{|c|c|c|}
\hline & & $\begin{array}{l}\text { la derrota de las mismas, España } \\
\text { quedo al margen del Plan Marshall. } \\
\text { Debido a la Guerra Fría y a la posición } \\
\text { estratégica de España, Estados Unidos } \\
\text { se volvió a interesar por reanudar las } \\
\text { relaciones, cristalizándose en el pacto } \\
\text { de Madrid en } 1953 \text { y la entrada de } \\
\text { España en las Naciones Unidas en } \\
1955 \text {. Con la muerte de Franco, España } \\
\text { y Estados Unidos firmaron un tratado } \\
\text { de Amistad y Cooperación que llevo a } \\
\text { España a entrar en } 1982 \text { en la } \\
\text { Organización del Tratado del Atlántico } \\
\text { Norte. Tras las elecciones generales del } \\
28 \text { de octubre de } 1982, \text { se produjo un } \\
\text { periodo de reflexión sobre la entrada } \\
\text { de España en la Alianza, que condujo a } \\
\text { la suspensión de las conversaciones } \\
\text { sobre la integración militar española en } \\
\text { la OTAN. }\end{array}$ \\
\hline 7:03 & $\begin{array}{l}\text { Cantan: "Mañana España, será } \\
\text { Republicana". }\end{array}$ & $\begin{array}{l}\text { Hasta la aprobación de la constitución } \\
\text { en } 1978, \text { fue el grito de los } \\
\text { republicanos españoles durante la } \\
\text { transición. }\end{array}$ \\
\hline 7:42 & $\begin{array}{l}\text { Princesa Isabel (a un conspirador } \\
\text { republicano): "Tú que tienes cara } \\
\text { de rojillo escúpeme". } \\
\text { Conspirador: "No puedo alteza, yo } \\
\text { soy euro rojillo". }\end{array}$ & $\begin{array}{l}\text { "Euro Rojillo" entiéndase como } \\
\text { Eurocomunista. Tendencia de distintos } \\
\text { partidos comunistas de Europa } \\
\text { occidental en los cuales se renunciaba } \\
\text { al modelo soviético y se aceptaban las } \\
\text { "libertades burguesas". En el caso del } \\
\text { PCE el reconocimiento de la monarquía } \\
\text { parlamentaria. }\end{array}$ \\
\hline 7:48 & $\begin{array}{l}\text { Princesa Isabel (al Tabernero): } \\
\text { "¿Estos son conspiradores de } \\
\text { izquierdas antimonárquicos?" } \\
\text { Tabernero: "Andan por la línea } \\
\text { monárquica de Fray Carrillo el } \\
\text { Obispo de Paracuellos". }\end{array}$ & $\begin{array}{l}\text { Destacado dirigente comunista español } \\
\text { en la defensa de Madrid durante la } \\
\text { Guerra Civil, ostentó el cargo de } \\
\text { consejero de orden público, momento } \\
\text { donde tienen lugar los fusilamientos de } \\
\text { Paracuellos, cuya responsabilidad en } \\
\text { los mismo sigue siendo muy polémica a } \\
\text { día de hoy. Durante la transición y } \\
\text { como secretario general del partido } \\
\text { comunista fue una figura destacada, } \\
\text { desde posturas radicales que defendían } \\
\text { una república en España, pasó tras la } \\
\text { legalización del PCE, a admitir la } \\
\text { monarquía constitucional. }\end{array}$ \\
\hline 7:58 & $\begin{array}{l}\text { Princesa Isabel: "Pues me tratan } \\
\text { con un respeto como si fuera los } \\
\text { hermanos Ansón". }\end{array}$ & $\begin{array}{l}\text { Rafael, Luis María y Francisco Ansón } \\
\text { Oliart. Sobre todo los dos primeros } \\
\text { fueron personas muy conocidas } \\
\text { durante la transición democrática, el } \\
\text { primero como director de Radio } \\
\text { Televisión Española (1976-1979), y el } \\
\text { segundo como Presidente de la } \\
\text { Agencia EFE (1976-1983), los dos } \\
\text { medios de comunicación públicos más } \\
\text { importantes que existían en ese }\end{array}$ \\
\hline
\end{tabular}


Fernández Paradas, A. R., y Sánchez Guzmán, R. La cosmovisión de la Transición española en la película Juana la Loca... de vez en cuando un manual para la comprensión de la comedia histórica de los ochenta

\begin{tabular}{|c|c|c|}
\hline & & $\begin{array}{l}\text { momento. Este último sigue siendo uno } \\
\text { de los más conocidos periodistas de } \\
\text { ideología monárquica en España, al } \\
\text { haber pertenecido al consejo privado } \\
\text { del Conde de Barcelona (también fue } \\
\text { su biógrafo) y director del periódico } \\
\text { monárquico ABC (1983-1997). }\end{array}$ \\
\hline $8: 39$ & $\begin{array}{l}\text { Princesa Isabel (al Tabernero): } \\
\text { "Seguiremos conspirando en la } \\
\text { Cafetería Galaxia el lunes". }\end{array}$ & $\begin{array}{l}\text { Operación Galaxia fue el nombre en } \\
\text { clave dado a un plan golpista que tuvo } \\
\text { lugar en } 1978 \text { durante la Transición } \\
\text { española. Toma su nombre de la } \\
\text { Cafetería Galaxia de Madrid (actual Van } \\
\text { Gogh café) donde los oficiales que lo } \\
\text { formaban se reunieron el } 11 \text { de } \\
\text { noviembre de } 1978 \text {. }\end{array}$ \\
\hline $8: 46$ & $\begin{array}{l}\text { Tabernero (a la Princesa Isabel): } \\
\text { "¿Y los cafés quien me los paga? } \\
\text { Princesa Isabel: "Toma y con las } \\
\text { vueltas alquila seis carromatos en } \\
\text { la Sepulvedana". }\end{array}$ & $\begin{array}{l}\text { La Sepulvedana es una compañía de } \\
\text { Autobuses Española. Durante el golpe } \\
\text { de Estado del } 23 \text { de febrero de } 1981, \\
\text { la mujer del teniente coronel Antonio } \\
\text { Tejero compró a esta compañía los } \\
\text { autobuses para trasladar a los militares } \\
\text { golpistas. }\end{array}$ \\
\hline $8: 51$ & $\begin{array}{l}\text { Princesa Isabel (al Tabernero): } \\
\text { "Tranquilo, los geos no me } \\
\text { cogerán nunca". }\end{array}$ & $\begin{array}{l}\text { GEO, Grupo Especial de Operaciones, } \\
\text { creado por el Ministro del Interior de la } \\
\text { Unión de Centro Democrático (UCD) } \\
\text { Rodolfo Martín Villa en 1977, tras los } \\
\text { sucesos de las Olimpiadas de Múnich } \\
1972 \text {, con la toma de rehenes por un } \\
\text { comando palestino y posterior } \\
\text { asesinato de atletas israelíes, si bien no } \\
\text { fue operativa hasta } 1979 \text {. Su presencia } \\
\text { en la sociedad española de finales de } \\
\text { los setenta y principio de los ochenta } \\
\text { fue muy activa y mediática. Golpe de } \\
\text { Estado del } 23 \text { de Febrero de } 1981 \text { en } \\
\text { Madrid, en Barcelona el intento de robo } \\
\text { del Banco Central en } 1981 .\end{array}$ \\
\hline 9:05 & $\begin{array}{l}\text { Torquemada (al carcelero): "¿Ha } \\
\text { pedido algo a parte del } \\
\text { abogado?". } \\
\text { Carcelero: "Un recado con que } \\
\text { escribir y un ejemplar del Alcázar } \\
\text { para reírse". }\end{array}$ & $\begin{array}{l}\text { El Alcázar fue un diario editado en } \\
\text { Madrid con entre } 1936 \text { y } 1987 \text {. Tras la } \\
\text { muerte de Franco, se convirtió en el } \\
\text { medio de expresión del llamado } \\
\text { Búnker, el grupo de dirigentes, } \\
\text { militares y ex-militares franquistas } \\
\text { opuestos a la transición a la } \\
\text { democracia. }\end{array}$ \\
\hline $9: 22$ & $\begin{array}{l}\text { Isabel la Católica (a los } \\
\text { conspiradores republicanos): "¿De } \\
\text { manera que no os gustamos? } \\
\text { ¿Qué queréis cambiar de régimen } \\
\text { así por las buenas...? Yo soy } \\
\text { Isabel la Católica la que hizo la } \\
\text { unidad de la patria la que arrojó } \\
\text { al infiel ¿Qué más hice } \\
\text { Torquemada?". } \\
\text { Torquemada (a Isabel): } \\
\text { "Descubrir América e incautar }\end{array}$ & $\begin{array}{l}\text { Nueva alusión al golpe de estado del } \\
23 \text { de febrero de 1981, e identificación } \\
\text { del gobierno socialista con el reinado } \\
\text { de los Reyes Católicos. Galerías } \\
\text { Preciados, fue un grupo español de } \\
\text { grandes almacenes, fundado en } 1943 \text { y } \\
\text { desaparecido en 1995. En } 1983 \\
\text { pertenecía al grupo Rumasa cuando } \\
\text { fue expropiado por el Estado. }\end{array}$ \\
\hline
\end{tabular}


Fernández Paradas, A. R., y Sánchez Guzmán, R. La cosmovisión de la Transición española en la película Juana la Loca... de vez en cuando un manual para la comprensión de la comedia histórica de los ochenta

\begin{tabular}{|c|c|c|}
\hline & $\begin{array}{l}\text { Galerías Preciados para la } \\
\text { Corona". }\end{array}$ & \\
\hline 9:49 & $\begin{array}{l}\text { Isabel la Católica (a los } \\
\text { conspiradores): "Y ustedes andáis } \\
\text { asociándose ilegalmente para } \\
\text { ponerme como un trapo". } \\
\text { Fernando el Católico: "Como un } \\
\text { trapo del Corte Inglés...". }\end{array}$ & $\begin{array}{l}\text { Grupo formado por empresas de } \\
\text { distintos formatos, siendo el principal } \\
\text { el de grandes almacenes, fundada en } \\
\text { 1940. La rivalidad comercial entre esta } \\
\text { y Galerías Preciados, acabo en } 1995 \\
\text { cuando esta última fue absorbida por } \\
\text { la primera. }\end{array}$ \\
\hline $11: 54$ & $\begin{array}{l}\text { Fernando el Católico (a su hija } \\
\text { Juana): "Ofreceremos una dote } \\
\text { importante, la Banca Catalana por } \\
\text { ejemplo". }\end{array}$ & $\begin{array}{l}\text { La Banca Catalana fue una entidad } \\
\text { financiera catalana creada en } 1959 \text { y } \\
\text { absorbida en } 1988 \text { por el Banco Bilbao } \\
\text { Vizcaya. En } 1981 \text { era el primer grupo } \\
\text { bancario catalán y el décimo español. } \\
\text { En } 1982 \text { entró en una sonora crisis con } \\
\text { tintes políticos, al ser la familia Pujol, } \\
\text { su fundadora y por entonces el que } \\
\text { había sido directivo en los años } \\
\text { setenta, Jordi Pujol, era presidente de } \\
\text { la Generalidad de Cataluña. }\end{array}$ \\
\hline $11: 59$ & $\begin{array}{l}\text { Isabel la Católica (a su hija } \\
\text { Juana): "Holding, mucho holding, } \\
\text { empezando por el Opus y } \\
\text { terminando por las Torres de } \\
\text { Colón". }\end{array}$ & $\begin{array}{l}\text { Holding, término alusivo al grupo de } \\
\text { empresas de Rumasa, cuya sede social } \\
\text { eran las significativas Torres de Colón } \\
\text { en Madrid, construidas entre ente } 1967 \\
\text { y } 1976 \text { por el arquitecto Antonio } \\
\text { Lamela. El presidente del grupo, José } \\
\text { María Ruiz Mateos fue un destacado } \\
\text { miembro del Opus Dei, instituto } \\
\text { perteneciente a la Iglesia Católica. }\end{array}$ \\
\hline $12: 18$ & $\begin{array}{l}\text { Juana la Loca (a sus padres): } \\
\text { "Quiero quedarme embarazada } \\
\text { para me coja cuando } \\
\text { despenalicen el aborto". }\end{array}$ & $\begin{array}{l}\text { Desde la llegada del PSOE al poder en } \\
1982, \text { y amparado por los movimientos } \\
\text { feministas, se fue trazando la Ley de } \\
\text { Aborto, no sin mucha polémica, que } \\
\text { finalmente vio la luz por Ley Orgánica } \\
\text { 9/1985, aprobada el } 5 \text { de julio de } \\
\text { 1985, donde se despenalizaba en tres } \\
\text { supuestos. }\end{array}$ \\
\hline $12: 23$ & $\begin{array}{l}\text { Isabel la Católica (a su hija } \\
\text { Juana): "Te buscaremos al más } \\
\text { culto y al más católico que } \\
\text { encontremos en este país: Tierno } \\
\text { Galván". }\end{array}$ & $\begin{array}{l}\text { Enrique Tierno Galván (Madrid, 1916- } \\
\text { 1986), fue un popular y carismático } \\
\text { alcalde socialista de Madrid entre } 1979 \\
\text { y } 1986 . \text { Su labor como alcalde suscitó } \\
\text { una unanimidad a su favor, que fue } \\
\text { más allá de ideologías políticas. } \\
\text { También es conocido como el alcalde } \\
\text { de la Movida Madrileña. }\end{array}$ \\
\hline $12: 35$ & $\begin{array}{l}\text { Juana la Loca: "Quiero casarme y } \\
\text { tener muchos hijos al primero le } \\
\text { haré emperador y al pequeño le } \\
\text { haré de Comisiones". }\end{array}$ & $\begin{array}{l}\text { Confederación Sindical de Comisiones } \\
\text { Obreras (C. S. de CC. OO.) o Comisiones } \\
\text { Obreras (CC. OO.), es una confederación } \\
\text { sindical española, vinculada en sus } \\
\text { orígenes al Partido Comunista de } \\
\text { España, aunque independiente de } \\
\text { cualquier partido político. }\end{array}$ \\
\hline $14: 57$ & $\begin{array}{l}\text { Cisneros (a Torquemada): "¿No } \\
\text { queréis acompañarme y os } \\
\text { presente a mi pedicuro? Es clavao } \\
\text { a Calviño, igualito, igualito". }\end{array}$ & $\begin{array}{l}\text { José María Calviño (Lalín, Pontevedra } \\
\text { 1943) fue director de Radio Televisión } \\
\text { Española desde } 1982 \text { a } 1886 .\end{array}$ \\
\hline
\end{tabular}


Fernández Paradas, A. R., y Sánchez Guzmán, R. La cosmovisión de la Transición española en la película Juana la Loca... de vez en cuando un manual para la comprensión de la comedia histórica de los ochenta

\begin{tabular}{|c|c|c|}
\hline $17: 25$ & $\begin{array}{l}\text { Fernando el Católico (a Colón): } \\
\text { "¿Entonces os hace un estanco?" }\end{array}$ & $\begin{array}{l}\text { Durante el Franquismo la concesión de } \\
\text { licencias de estancos (entre otras) se } \\
\text { hizo de manera arbitraria y partidista. }\end{array}$ \\
\hline $17: 54$ & $\begin{array}{l}\text { Colón (a los Reyes Católicos): "iY } \\
\text { gobernador civil y jefe provincial } \\
\text { del movimiento hispanista!" }\end{array}$ & $\begin{array}{l}\text { Alusión al Consejo Nacional del } \\
\text { Movimiento, institución franquista de } \\
\text { carácter colegiado, que estaba } \\
\text { subordinada a la Jefatura del Estado, } \\
\text { creada durante la Guerra Civil, y que } \\
\text { quedó disuelta en } 1977 .\end{array}$ \\
\hline $18: 10$ & $\begin{array}{l}\text { Torquemada (a Isabel la } \\
\text { Católica): "No pasa nada } \\
\text { majestad, yo creo que le debéis } \\
\text { nombrar varón de Rumasa". }\end{array}$ & $\begin{array}{l}\text { Nueva referencia a Rumasa y José } \\
\text { María Ruiz Mateos. }\end{array}$ \\
\hline $18: 17$ & $\begin{array}{l}\text { Cisneros (a los Reyes Católicos): } \\
\text { "Debemos darles cultura y religión } \\
\text { y que elijan la autonomía que } \\
\text { prefieran, que de eso...". }\end{array}$ & $\begin{array}{l}\text { La organización territorial de España, } \\
\text { como un estado autonómico, se basa en } \\
\text { el artículo } 2 \text { de la Constitución de 1978, } \\
\text { donde se garantiza el derecho a la } \\
\text { autonomía de las nacionalidades y } \\
\text { regiones, quedando desarrollado en el } \\
\text { Título VIII, artículo 137, sobre la } \\
\text { organización territorial del estado. Entre } \\
1979 \text { y } 1983 \text { tuvo lugar la aprobación } \\
\text { de los } 17 \text { estatutos de Autonomía, a los } \\
\text { que se añadieron en } 1995 \text { Ceuta y } \\
\text { Melilla como ciudades autónomas. }\end{array}$ \\
\hline $18: 28$ & $\begin{array}{l}\text { Colón (a los Reyes Católicos): "La } \\
\text { chispa de la vida, una bebida } \\
\text { autóctona, que mezclada con ron } \\
\text { la llaman Cubata". }\end{array}$ & $\begin{array}{l}\text { El slogan "Coke adds Life", traducido } \\
\text { en España como "La chispa de la vida" } \\
\text { de la marca Coca Cola, empresa creada } \\
\text { en } 1886, \text { fue creado en } 1972 \text { por la } \\
\text { agencia publicitaria McCann, y } \\
\text { acompañó a la compañía durante los } \\
\text { años 70, hasta que en } 1982 \text { fue } \\
\text { sustituido por "Coca Cola es así" } \\
\text { ("Coke is It"). } \\
\text { El Cubata o Cuba libre, tiene su origen } \\
\text { en La Habana (Cuba) a finales del siglo } \\
\text { XIX, durante la guerra entre Estados } \\
\text { Unidos y España. Las fuerzas } \\
\text { norteamericanas mezclaban } \\
\text { regularmente ron y bebida de cola, } \\
\text { conociéndose como cuba libre, en } \\
\text { honor al grito de batalla de las tropas } \\
\text { cubanas. }\end{array}$ \\
\hline $20: 13$ & $\begin{array}{l}\text { Heraldo leyendo un bando por la } \\
\text { muerte del príncipe Juan: "Sus } \\
\text { Majestades, Los Reyes Católicos } \\
\text { hacen saber a toda España, que } \\
\text { se declara luto riguroso por la } \\
\text { muerte del infante don Juan } \\
\text { durante tres años. Se decapitarán } \\
\text { todos los días veinte presos } \\
\text { políticos, judíos moros y demás } \\
\text { ciudadanos que no lleven en regla } \\
\text { el certificado de penales y de } \\
\text { buena conducta. Queda prohibido } \\
\text { reírse y usar ropas que no sean }\end{array}$ & $\begin{array}{l}\text { El Futbol Club Barcelona (Barça). } \\
\text { Aunque los años ochenta fueron años } \\
\text { de inversiones en fichaje de grandes } \\
\text { estrellas, no se correspondió con éxitos } \\
\text { deportivos. De los títulos españoles } \\
\text { solo consiguieron una liga, tres Copas } \\
\text { del Rey, una Supercopa y dos Copas } \\
\text { de la Liga, y de los europeos dos } \\
\text { Recopas de Europa. }\end{array}$ \\
\hline
\end{tabular}


Fernández Paradas, A. R., y Sánchez Guzmán, R. La cosmovisión de la Transición española en la película Juana la Loca... de vez en cuando un manual para la comprensión de la comedia histórica de los ochenta

\begin{tabular}{|c|c|c|}
\hline & $\begin{array}{l}\text { negras. Al ponerse el sol nadie } \\
\text { podrá salir de su casa... y sus } \\
\text { ciudadanos tienen que tener el } \\
\text { semblante como si fueras socios } \\
\text { del Barça". }\end{array}$ & \\
\hline $20: 55$ & $\begin{array}{l}\text { Torquemada (a un acusado por la } \\
\text { Inquisición): "...serán confiscadas } \\
\text { sus tierras, sus riquezas. Y hasta } \\
\text { la abeja, ingresando en la prisión } \\
\text { militar de Alcalá de Henares } \\
\text { donde podrá recibir visitas los } \\
\text { sábados y días de vigilia". }\end{array}$ & $\begin{array}{l}\text { Nuevas alusiones a Rumasa (abeja) } \\
\text { mezcladas con el golpe de Estado del } \\
23 \text { de Febrero de } 1981 \text { (prisión militar } \\
\text { de Alcalá de Henares, donde estuvo } \\
\text { preso el teniente coronel Tejero y otros } \\
\text { militares y guardia civiles que } \\
\text { participaron en el golpe. }\end{array}$ \\
\hline 21:09 & $\begin{array}{l}\text { Torquemada (a un acusado por la } \\
\text { Inquisición): "También se le acusa } \\
\text { de golpista, genocidio y agente de } \\
\text { la CIA al servicio del imperialismo } \\
\text { yanqui". }\end{array}$ & $\begin{array}{l}\text { Durante los ochenta, grupos políticos } \\
\text { de izquierda hicieron campaña en } \\
\text { contra de la presencia estadounidense } \\
\text { en España (Bases Militares) y se } \\
\text { presionó mucho para que se redujera, } \\
\text { dando lugar en } 1986 \text { al referéndum de } \\
\text { la permanencia de España en OTAN. }\end{array}$ \\
\hline $21: 21$ & $\begin{array}{l}\text { Torquemada (a un acusado por la } \\
\text { Inquisición): "Claro que, por } \\
\text { buena conducta, redención de } \\
\text { penas por el trabajo y la visita del } \\
\text { Papa, podrá salir dentro de un } \\
\text { mes". }\end{array}$ & $\begin{array}{l}\text { La primera visita de un Papa a España } \\
\text { fue la de Juan Pablo II en } 1982 \text {. Su } \\
\text { visita tuvo lugar del día } 31 \text { de octubre } \\
\text { al } 9 \text { de noviembre y fue el viaje más } \\
\text { largo de los que realizaría } \\
\text { posteriormente. }\end{array}$ \\
\hline $21: 45$ & $\begin{array}{l}\text { Isabel la Católica (a Juana): "Los } \\
\text { pretendientes que nos mandó } \\
\text { Elena Francis no son } \\
\text { presentables...". }\end{array}$ & $\begin{array}{l}\text { El Consultorio de Elena Francis fue un } \\
\text { programa de radio emitido en España } \\
\text { entre los años } 1947 \text { y } 1984 .\end{array}$ \\
\hline $24: 10$ & $\begin{array}{l}\text { Juana la Loca (a Isabel la } \\
\text { Católica): "El hombre portugués } \\
\text { tiene fama de guapo". } \\
\text { Isabel la Católica: "¿Te gusta un } \\
\text { portugués?" } \\
\text { Juana: "Si". } \\
\text { Isabel: "Hay un descendiente de } \\
\text { Simao da Veiga rejoneador, con } \\
\text { caballo, eh, con caballo y todo". }\end{array}$ & $\begin{array}{l}\text { Simao da Veiga (1903-1959), uno de } \\
\text { los rejoneadores portugueses más } \\
\text { importantes de todos los tiempos. } \\
\text { Sírvanos el ejemplo que durante la } \\
\text { temporada de } 1927 \text { en España, fue el } \\
\text { rejoneador con mayor número de } \\
\text { corridas y el primero en conseguir una } \\
\text { oreja en Las Ventas madrileñas. }\end{array}$ \\
\hline $25: 59$ & $\begin{array}{l}\text { Pinto Gorgorao (a Juana): "Pues } \\
\text { la verdad es que estoy operado". } \\
\text { Juana la Loca: "¿Apéndice?". } \\
\text { Pinto: "No por Dios no tanto. Un } \\
\text { vulgar y simple cambio de sexo". } \\
\text { Juana la Loca: "Eso quiere decir } \\
\text { que sois un travesti". } \\
\text { Pinto: "Hasta que tuve la mayoría } \\
\text { de edad fui una mujer". }\end{array}$ & $\begin{array}{l}\text { Hasta } 1979 \text { la transexualidad en } \\
\text { España fue penalizada según la Ley de } \\
\text { Peligrosidad Social (1970). } \\
\text { En el periodo pre gay (1970-1982), el } \\
\text { término que nombra la realidad } \\
\text { transgénero en España es travestí }{ }^{2} \text { Si } \\
\text { tuviéramos que marcar un hito en la } \\
\text { visibilidad de la transexualidad } \\
\text { (femenina) sería la película Cambio de } \\
\text { sexo, dirigida por Vicente Aranda en } \\
\text { 1977, con el debut cinematográfico de } \\
\text { Bibiana Fernández, el éxito de la } \\
\text { película de Aranda la convirtió en un } \\
\text { personaje popular rápidamente. }\end{array}$ \\
\hline
\end{tabular}

2 Guasch O., \& Mas, J. (2014). La construcción médico-social de la transexualidad en España (19702014). Gazeta de Antropología, 3a(3). Recuperado de http://www.gazeta-antropologia.es/?p=4619 
Fernández Paradas, A. R., y Sánchez Guzmán, R. La cosmovisión de la Transición española en la película Juana la Loca... de vez en cuando un manual para la comprensión de la comedia histórica de los ochenta

\begin{tabular}{|c|c|c|}
\hline 29:39 & $\begin{array}{l}\text { Juana la Loca (a los Reyes } \\
\text { católicos): "Y además se llama } \\
\text { Felipe, como Felipe González". }\end{array}$ & $\begin{array}{l}\text { Felipe González Márquez (1942- ), por } \\
\text { entonces (1983) presidente del } \\
\text { Gobierno de España, tras alcanzar su } \\
\text { partido el PSOE, en las elecciones de } \\
\text { 1982, la mayor mayoría absoluta en el } \\
\text { Congreso de los Diputados desde } 1977 \\
\text { (202, de } 350 \text { escaños). Fue la primera } \\
\text { ocasión desde la época de la Segunda } \\
\text { República que un partido de izquierdas } \\
\text { ganaba unas elecciones generales. }\end{array}$ \\
\hline $33: 17$ & $\begin{array}{l}\text { Juana (a los Reyes Católicos): } \\
\text { "Dile que soy honesta, pura, } \\
\text { virginal y antiaborto". }\end{array}$ & $\begin{array}{l}\text { Como se ha visto con anterioridad, la } \\
\text { redacción y aprobación de la Ley del } \\
\text { Aborto no estuvo exenta de polémica, } \\
\text { finalmente fue a aprobada en } 1985 \text {. }\end{array}$ \\
\hline $33: 49$ & $\begin{array}{l}\text { Heraldo: "La Santa Inquisición } \\
\text { acaba de dictar la Ley de } \\
\text { Incompatibilidades". }\end{array}$ & $\begin{array}{l}\text { Son varias escenas que, comenzando } \\
\text { con esta, siguiendo con el discurso de } \\
\text { Torquemada, continuando con la } \\
\text { manifestación y terminando con la } \\
\text { extracción de una muela a } \\
\text { Torquemada, es una crítica a una } \\
\text { práctica bastante habitual por } \\
\text { entonces, aquí enfocada } \\
\text { fundamentalmente al sector de la } \\
\text { medicina, en donde los facultativos } \\
\text { compatibilizaban su trabajo en la } \\
\text { sanidad pública, con otros en } \\
\text { sociedades privadas o consultas } \\
\text { propias. Todo esto dio lugar a la Ley } \\
\text { Orgánica 53/84, de } 26 \text { de diciembre de } \\
\text { 1984, de Incompatibilidades del } \\
\text { personal al servicio de las } \\
\text { Administraciones Públicas. }\end{array}$ \\
\hline 19:16 & $\begin{array}{l}\text { Torquemada (al odontólogo): "Te } \\
\text { quedas sin pluriempleo, cierro la } \\
\text { consulta, y te quedas solo con La } \\
\text { Paz". }\end{array}$ & $\begin{array}{l}\text { El Hospital General La Paz se inauguró } \\
\text { el } 18 \text { de julio de } 1964 \text {, siendo en ese } \\
\text { momento el primer gran centro } \\
\text { hospitalario español. }\end{array}$ \\
\hline 40:00 & $\begin{array}{l}\text { Isabel la Católica (leyendo una } \\
\text { carta de Juana): "Y una faja para } \\
\text { mamá en la cual estoy bordando: } \\
\text { tanto monta monta tanto Isabel } \\
\text { como Fernando y ponga un } \\
\text { Vanguard en su vida". }\end{array}$ & $\begin{array}{l}\text { "ponga un Vanguard en su vida" } \\
\text { popular slogan publicitario de la } \\
\text { empresa Vanguard de televisores, } \\
\text { radios y radiocasetes. }\end{array}$ \\
\hline 41:30 & $\begin{array}{l}\text { Carcelero (a Torquemada): "¿Qué } \\
\text { hacemos con el Gran Capitán?". } \\
\text { Torquemada: "Que siga exiliado, } \\
\text { iNo quiero golpistas!". }\end{array}$ & $\begin{array}{l}\text { Nueva alusión al golpe de Estado del } \\
23 \text { de Febrero de } 1981 .\end{array}$ \\
\hline 44:09 & $\begin{array}{l}\text { Felipe el Hermoso (a Juana): } \\
\text { "Daremos una vuelta a la política } \\
\text { de tu país, haremos bajo nuestro } \\
\text { reinado una España alegre y } \\
\text { faldicorta. Abriremos casinos de } \\
\text { juego y pondremos casas de } \\
\text { masajes". }\end{array}$ & $\begin{array}{l}\text { En } 1977 \text { con la aprobación de la Ley } \\
\text { del Juego, se legalizó esta actividad en } \\
\text { España, abriendo los primeros } 18 \\
\text { casinos o salas de juego. El juego } \\
\text { estaba penalizado desde la dictadura } \\
\text { de Primo de Rivera. }\end{array}$ \\
\hline $45: 49$ & $\begin{array}{l}\text { Duque de Medina Sidonia (a } \\
\text { Juana y Felipe): "Socialista de } \\
\text { toda la vida, cuando Alfonso }\end{array}$ & $\begin{array}{l}\text { (Sevilla, 1940) político español, } \\
\text { vicesecretario general del PSOE entre } \\
1979 \text { y } 1997, \text { vicepresidente del }\end{array}$ \\
\hline
\end{tabular}


Fernández Paradas, A. R., y Sánchez Guzmán, R. La cosmovisión de la Transición española en la película Juana la Loca... de vez en cuando un manual para la comprensión de la comedia histórica de los ochenta

\begin{tabular}{|c|c|c|}
\hline & $\begin{array}{l}\text { Guerra vendía libros en Sevilla, } \\
\text { era yo quien los escribía". }\end{array}$ & $\begin{array}{l}\text { Gobierno entre } 1982 \text { y } 1991 \text { y una de } \\
\text { las figuras políticas más determinantes } \\
\text { de la escena política española durante } \\
\text { la Transición. }\end{array}$ \\
\hline $46: 05$ & $\begin{array}{l}\text { Marques de Priego (a Juana y } \\
\text { Felipe): "Y jure con vuestros } \\
\text { padres los principios nacionales } \\
\text { del movimiento". }\end{array}$ & $\begin{array}{l}\text { Irónica referencia a Ley de Principios del } \\
\text { Movimiento Nacional o Ley de Principios } \\
\text { Fundamentales del Movimiento, } \\
\text { promulgada en } 1958, \text { donde se } \\
\text { establecían los principios en los cuales } \\
\text { estaba basado el régimen de Franco. }\end{array}$ \\
\hline $47: 28$ & $\begin{array}{l}\text { Felipe el Hermoso (a Torquemada): } \\
\text { "He pensado que Burgos tiene que } \\
\text { tener vida nocturna... que le } \\
\text { parecen unos locales a base de } \\
\text { topless. Luego, el porro no es malo, } \\
\text { deberíamos de autorizarlo. }\end{array}$ & $\begin{array}{l}\text { Tras la muerte de Franco y tras años } \\
\text { de férrea represión la época de la } \\
\text { Transición estuvo marcada por la } \\
\text { libertad moral, dándose el "destape" en } \\
\text { el cine, o la aparición de bares de } \\
\text { topless o barra americana, donde las } \\
\text { trabajadoras atendían con los pechos } \\
\text { sin cubrir. Similar caso ocurrió con la } \\
\text { vida nocturna con fenómenos tan } \\
\text { conocidos como "La Movida } \\
\text { Madrileña". }\end{array}$ \\
\hline $52: 55$ & $\begin{array}{l}\text { Marques de Priego (a Felipe): } \\
\text { "Una venta por la carretera de La } \\
\text { Coruña que de madrugada dan } \\
\text { pepitos y ensaladas". }\end{array}$ & $\begin{array}{l}\text { Los numerosos prostíbulos de } \\
\text { carreteras que poblaban por entonces } \\
\text { la nacional V en sus cercanías a } \\
\text { Madrid. }\end{array}$ \\
\hline $54: 56$ & $\begin{array}{l}\text { Zoraida (al tabernero): "iVicente!, } \\
\text { marchando un paquete de } \\
\text { Winston". }\end{array}$ & $\begin{array}{l}\text { Winston es una marca de cigarrillos } \\
\text { creada en } 1954 \text {. Tras su lanzamiento } \\
\text { se convirtió en la marca americana } \\
\text { más conocida de cigarrillos con filtro. }\end{array}$ \\
\hline $57: 18$ & $\begin{array}{l}\text { Juana: "¿Qué sabéis de una } \\
\text { mora?, ¿Una tal Zoraida? Que } \\
\text { actuaba en este local y movía el } \\
\text { ombligo con pilas". } \\
\text { Cliente: "me parece que se ha ido } \\
\text { a Eurovisión". }\end{array}$ & $\begin{array}{l}\text { El Festival de la Canción de Eurovisión } \\
\text { (primera edición 1956) es un concurso } \\
\text { televisivo de canciones de carácter } \\
\text { anual, en el que participan intérpretes } \\
\text { representantes de las televisiones } \\
\text { pertenecientes a la Unión Europea de } \\
\text { Radiodifusión. }\end{array}$ \\
\hline $57: 26$ & $\begin{array}{l}\text { Vicente: "Perdonadme Majestad, } \\
\text { hace una semana que dejo el } \\
\text { alterne, un hermoso caballero la } \\
\text { retiró y le compró un Fiesta. } \\
\text { Juana la Loca: "¿Y podéis decir su } \\
\text { paradero?" } \\
\text { Vicente: "Pues veréis... Por } \\
\text { Leganitos 128, el barrio de la } \\
\text { judería, por Capitán Haya, con } \\
\text { plaza de garaje y aire } \\
\text { acondicionado". }\end{array}$ & $\begin{array}{l}\text { Ford Fiesta, icono automovilístico de } \\
\text { una época, desde empezó a producirse } \\
\text { en } 1976 \text {. Durante el trienio (1978, } \\
1979 \text { y 1980) el modelo de automóvil } \\
\text { más vendido en España fue el Ford } \\
\text { Fiesta. }\end{array}$ \\
\hline 1:02:59 & $\begin{array}{l}\text { Juana la Loca (a Cisneros y } \\
\text { Torquemada): "Todas las moras, } \\
\text { que no demuestren un trabajo } \\
\text { serio y honrado... serán } \\
\text { encarceladas hasta nueva orden. } \\
\text { Cisneros: "Majestad, nos puede } \\
\text { traer problemas y no nos van a } \\
\text { dejar pescar". }\end{array}$ & $\begin{array}{l}\text { La pesca marítima ha constituido } \\
\text { tradicionalmente un capítulo de } \\
\text { especial relevancia en las relaciones } \\
\text { entre España y Marruecos. Los } \\
\text { acuerdos pesqueros, de vital } \\
\text { importancia para España, han sido } \\
\text { utilizados tradicionalmente por } \\
\text { Marruecos para obtener mayores } \\
\text { compensaciones de toda índole y han }\end{array}$ \\
\hline
\end{tabular}


Fernández Paradas, A. R., y Sánchez Guzmán, R. La cosmovisión de la Transición española en la película Juana la Loca... de vez en cuando un manual para la comprensión de la comedia histórica de los ochenta

\begin{tabular}{|c|c|c|}
\hline & & $\begin{array}{l}\text { estado jalonados de numerosos } \\
\text { conflictos. }\end{array}$ \\
\hline 1:04:29 & $\begin{array}{l}\text { Torquemada (a Felipe): "¿Creéis } \\
\text { que el congreso y la alta cámara } \\
\text { accederá a su inhabilitación?". } \\
\text { Felipe: "Seguro, tendrán que } \\
\text { aceptar mis órdenes. Y si no a la } \\
\text { calle". } \\
\text { Torquemada: "iSí!, iSí! iA la calle! } \\
\text { no dimite pase lo que pase". }\end{array}$ & $\begin{array}{l}\text { Tras la constitución de 1978, se volvió } \\
\text { a establecer en España el sistema } \\
\text { Bicameral, el Congreso de los } \\
\text { Diputados (Cámara Baja) y Senado } \\
\text { (Cámara Alta). } \\
\text { Gregorio Peces-Barba (1938-2012). } \\
\text { Político Socialista que ostentó el cargo } \\
\text { de presidente del Congreso de los } \\
\text { Diputados desde } 1982 \text { a } 1986 .\end{array}$ \\
\hline 1:05:08 & $\begin{array}{l}\text { Presidente de las Cortes: "Y oídas } \\
\text { las opiniones de cuantas personas } \\
\text { autorizadas por las leyes... y los } \\
\text { dictámenes de dos médicos de la } \\
\text { Seguridad Social y uno de Sanitas. } \\
\text { Decidimos, con vuestro Real } \\
\text { consentimiento, recluir a la reina } \\
\text { en el monasterio de las Huelgas". }\end{array}$ & $\begin{array}{l}\text { Tras la muerte de Franco, tanto en el } \\
\text { periodo preconstitucional como en el } \\
\text { democrático fue un periodo convulso } \\
\text { de frecuentes huelgas. Sirvamos por } \\
\text { ejemplo las Huelgas Generales que se } \\
\text { sucedieron desde } 1975 \text { a } 1982 \text { (1976, } \\
1979 \text { y 1981). }\end{array}$ \\
\hline $1: 06: 13$ & $\begin{array}{l}\text { Maestro de ceremonias: "Plaza al } \\
\text { Rey Felipe de Hamburgo, } \\
\text { Archiduque de Austria... socio de } \\
\text { honor del Betis y amigo de Pitita } \\
\text { Ridruejo". }\end{array}$ & $\begin{array}{l}\text { Esperanza (Pitita) Ridruejo (1930- ). } \\
\text { Casada desde } 1957 \text { con un diplomático, } \\
\text { su presencia en los medios de } \\
\text { comunicación españoles fue muy usual } \\
\text { durante décadas como icono de la alta } \\
\text { sociedad madrileña. Las apariciones } \\
\text { marianas vinieron después. }\end{array}$ \\
\hline 1:06:33 & $\begin{array}{l}\text { Cisneros (proclamando títulos de } \\
\text { Juana): "Reina de Castila y de } \\
\text { León... duquesa de Suárez y de } \\
\text { Arias Navarro". }\end{array}$ & $\begin{array}{l}\text { El ducado de Suárez fue concedido por } \\
\text { el Rey Juan Carlos al ex presidente del } \\
\text { gobierno Adolfo Suárez en 1981, en } \\
\text { tanto que el título de marqués de Arias } \\
\text { Navarro fue concedido por el mismo } \\
\text { monarca al último presidente del } \\
\text { gobierno del franquismo Carlos Arias } \\
\text { Navarro en } 1976 \text {. }\end{array}$ \\
\hline $1: 08: 24$ & $\begin{array}{l}\text { Fernando el Católico (rezando el } \\
\text { Rosario): "Cuarto misterio } \\
\text { glorioso el crimen de los Urquijo". }\end{array}$ & $\begin{array}{l}\text { El crimen de los marqueses de Urquijo } \\
\text { fue el asesinato de María Lourdes de } \\
\text { Urquijo y Morenés, marquesa de } \\
\text { Urquijo y su marido Manuel de la Sierra } \\
\text { y Torres, el } 1 \text { de agosto de } 1980 \\
\text { cuando fueron tiroteados en su } \\
\text { residencia de Somosaguas. El } \\
\text { asesinato fue uno de los hechos } \\
\text { delictivos con mayor seguimiento } \\
\text { mediático en la historia de España. }\end{array}$ \\
\hline 1:09:40 & $\begin{array}{l}\text { Princesa Isabel: "Tras haberla } \\
\text { colocado su padre a jugar con la } \\
\text { panoplia, aparece junto a ellos } \\
\text { portando el yugo y las flechas". }\end{array}$ & $\begin{array}{l}\text { Otro evidente doble juego de } \\
\text { imágenes. El yugo y las flechas, } \\
\text { símbolos de los reyes Isabel y } \\
\text { Fernando, recolocados por la joven } \\
\text { princesa, siguiente el escudo de la } \\
\text { Falange Española, símbolo reconocible } \\
\text { del franquismo. }\end{array}$ \\
\hline 1:09:51 & $\begin{array}{l}\text { Isabel la Católica (a Fernando): } \\
\text { "Barcelona es bona si la bossa } \\
\text { sona". }\end{array}$ & $\begin{array}{l}\text { Refrán catalán: "Barcelona es buena si } \\
\text { la bolsa suena". Frase acuñada por los } \\
\text { comerciantes italianos, que decían que } \\
\text { Barcelona "era buena" si conseguían } \\
\text { vender sus mercancías. }\end{array}$ \\
\hline
\end{tabular}


Fernández Paradas, A. R., y Sánchez Guzmán, R. La cosmovisión de la Transición española en la película Juana la Loca... de vez en cuando un manual para la comprensión de la comedia histórica de los ochenta

\begin{tabular}{|c|c|c|}
\hline 1:10:04 & $\begin{array}{l}\text { Isabel la Católica (a Fernando): } \\
\text { "iViva el Betis manque pierda!" }\end{array}$ & $\begin{array}{l}\text { En el ámbito deportivo la frase ha } \\
\text { pasado a formar parte del slogan del } \\
\text { club de futbol Real Betis Balompié. La } \\
\text { frase procede de un himno de 1954, } \\
\text { cuando el club logró el ascenso a } \\
\text { segunda, tras la victoria con el Español } \\
\text { de Tetuán. }\end{array}$ \\
\hline 1:10:55 & $\begin{array}{l}\text { Cisneros (a Felipe, tras el partido } \\
\text { de tenis): "Muy bien, bravo } \\
\text { Majestad, jugáis que parecéis } \\
\text { sueco". }\end{array}$ & $\begin{array}{l}\text { Alusión al tenista sueco Björn Borg } \\
(1956-) \text {, que durante su época como } \\
\text { jugador (1973-1981), logró } 96 \text { torneos, } \\
\text { entre ellos } 5 \text { Wimbledon, } 6 \text { Roland } \\
\text { Garros y } 2 \text { Masters. Es considerado } \\
\text { como uno de los mejores tenistas } \\
\text { masculinos de la historia del tenis. }\end{array}$ \\
\hline $1: 12: 01$ & $\begin{array}{l}\text { San Francisco de Borja (a Juana): } \\
\text { "El rey vuestro esposo falleció } \\
\text { ayer de un corte de digestión". } \\
\text { Juana: "Bien..., publicar mañana } \\
\text { la esquela en el ABC". }\end{array}$ & $\begin{array}{l}\text { Desde su fundación en } 1903 \text { el Diario } \\
\text { ABC se convirtió en el interlocutor } \\
\text { "oficial" de la clase social más afín a la } \\
\text { ideología del periódico, para anunciar } \\
\text { el deceso de un familiar o ser querido. } \\
\text { Por sus páginas se han publicado casi } \\
\text { medio millón de esquelas. Llegándose } \\
\text { a decir «uno no se muere si no } \\
\text { aparece su esquela en } A B C » .\end{array}$ \\
\hline $1: 14: 22$ & $\begin{array}{l}\text { Frailes: "Un fraile, dos frailes, tres } \\
\text { frailes. Maricón el que no baile". }\end{array}$ & $\begin{array}{l}\text { Fue Adolfo Suárez en } 1978 \text { quien firmó } \\
\text { una modificación de la Ley de } \\
\text { Peligrosidad Social, donde quedó } \\
\text { despenalizada la homosexualidad en } \\
\text { España, entrando en vigor en el mes } \\
\text { de enero de } 1979 \text {. En el periodo pre } \\
\text { gay (1970-1982), la imagen de la } \\
\text { realidad homosexual en España es lo } \\
\text { "afeminado". Prototipo difundido por el } \\
\text { cine y la televisión. Buen ejemplo es el } \\
\text { papel de Alfredo Landa en la película } \\
\text { de Tito Fernández "No desearás al } \\
\text { vecino del quinto"(1970). No será } \\
\text { hasta la Transición cuando el cine } \\
\text { recoja esta situación con un enfoque } \\
\text { social diametralmente opuesto. "El } \\
\text { diputado" Eloy de la Iglesia (1979). }\end{array}$ \\
\hline $1: 15: 32$ & $\begin{array}{l}\text { Isabel la Católica (al auditorio): } \\
\text { "Querido público, no saben } \\
\text { ustedes con cuanta satisfacción } \\
\text { escucho estos aplausos que tanto } \\
\text { ánimo dan a vuestra reina. Como } \\
\text { verán he comenzado mi tournée } \\
\text { en Zamora en la cual me siento } \\
\text { muy satisfecha de tantos fieles } \\
\text { que han venido a aplaudirme y a } \\
\text { decirme ole, y ahora quiero pedir } \\
\text { un fuerte aplauso para mi marido } \\
\text { el rey Fernando que pasa fatigas } \\
\text { conmigo llevándome a las galas } \\
\text { de verano para que ustedes me } \\
\text { vean. Y ahora nos vamos para } \\
\text { Utrera después de dejar Zamora, }\end{array}$ & $\begin{array}{l}\text { Paralelismo entre la corte itinerante de } \\
\text { los Reyes Católicos y las galas de } \\
\text { verano de los artistas. Aquí Lola Flores } \\
\text { devenida en Isabel la Católica ejerce } \\
\text { de sí misma en su papel de artista y } \\
\text { cantante. El final de la disertación con } \\
\text { la exclamación "Viva España y Jerez" } \\
\text { es una clara alusión a su ciudad natal. }\end{array}$ \\
\hline
\end{tabular}


Fernández Paradas, A. R., y Sánchez Guzmán, R. La cosmovisión de la Transición española en la película Juana la Loca... de vez en cuando un manual para la comprensión de la comedia histórica de los ochenta

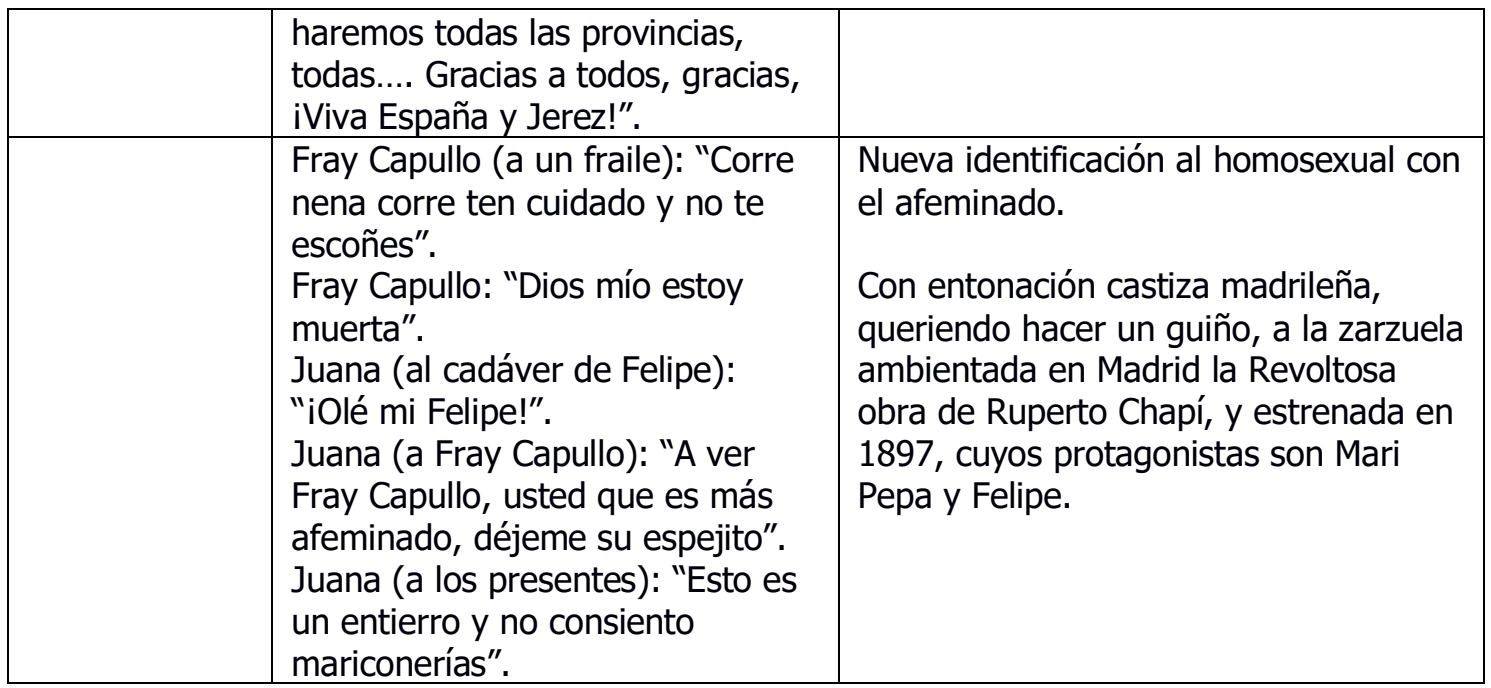

Fuente: Elaboración propia.

\subsection{El mundo de los objetos en Juana la Loca... de vez en cuando}

\section{Tabla 2}

\begin{tabular}{|c|c|c|}
\hline Minutado & & \\
\hline $0: 00$ & $\begin{array}{l}\text { Un pintor pinta una enorme } \\
\text { reproducción de un billete de } \\
\text { una peseta (1945). }\end{array}$ & $\begin{array}{l}\text { Enorme reproducción del billete de una peseta } \\
\text { con el rostro de Isabel la Católica (extraído del } \\
\text { cuadro de la rendición de granada de } \\
\text { Francisco Pradilla) emitido el } 15 \text { de junio de } \\
1945 \text {. Existe un cambio de fecha en la } \\
\text { reproducción para ajustarlo al reinado de los } \\
\text { Reyes Católicos: } 15 \text { de junio de } 1495, \text { por lo } \\
\text { demás la reproducción es exacta. Mientras el } \\
\text { pintor sigue retratando a la soberana en el } \\
\text { billete, este va desplazándose hace abajo } \\
\text { hasta quedar en el suelo, clara alusión a las } \\
\text { constantes bajadas y devoluciones de la } \\
\text { peseta en estos momentos. }\end{array}$ \\
\hline $1: 20$ & $\begin{array}{l}\text { Fernando porta una postal } \\
\text { turística enviada por Cristóbal } \\
\text { Colón con una vista } \\
\text { panorámica de los rascacielos } \\
\text { de Nueva York. }\end{array}$ & \\
\hline 2: 55 & $\begin{array}{l}\text { Juana lee un ejemplar de la } \\
\text { revista Rambla. }\end{array}$ & $\begin{array}{l}\text { Rambla fue una revista de historietas } \\
\text { publicada en España desde } 1982 \text { hasta 1985, } \\
\text { que formó parte del llamado boom del cómic } \\
\text { adulto en España difundiendo } \\
\text { exclusivamente material de autores } \\
\text { autóctonos, pero muy variado. }\end{array}$ \\
\hline 2: 55 & $\begin{array}{l}\text { Juana escucha música en un } \\
\text { Walkman. }\end{array}$ & $\begin{array}{l}\text { El Walkman, todo un icono de los años 1980, } \\
\text { era un reproductor de audio estéreo portátil } \\
\text { lanzado al mercado por la compañía } \\
\text { japonesa Sony en } 1979 .\end{array}$ \\
\hline $3: 05$ & $\begin{array}{l}\text { La princesa Isabel pinta con } \\
\text { spray negro en la pared } \\
\text { "Mañana España será }\end{array}$ & $\begin{array}{l}\text { Aunque no era un fenómeno nuevo, los años } \\
\text { de la Transición fueron pródigos en pintadas, } \\
\text { pero tras la democracia y la concesión de }\end{array}$ \\
\hline
\end{tabular}


Fernández Paradas, A. R., y Sánchez Guzmán, R. La cosmovisión de la Transición española en la película Juana la Loca... de vez en cuando un manual para la comprensión de la comedia histórica de los ochenta

\begin{tabular}{|c|c|c|}
\hline & republicana". & $\begin{array}{l}\text { muchas de esas reclamaciones, aunado a la } \\
\text { ausencia de esa clandestinidad que las } \\
\text { creaba, les hicieron perder incentivos. }\end{array}$ \\
\hline $3: 08$ & $\begin{array}{l}\text { Tres frailes dan clase a los } \\
\text { hijos de los Reyes Católicos } \\
\text { ante una pizarra encerada con } \\
\text { marco de madera, } \\
\text { característica de las escuelas } \\
\text { hasta la década de los setenta, }\end{array}$ & Marca no identificada. \\
\hline $5: 58$ & $\begin{array}{l}\text { Spray perfumador de } \\
\text { Torquemada. }\end{array}$ & \\
\hline $6: 55$ & Calculadora de escritorio. & \\
\hline $8: 34$ & No visual. Alarma de los GEO. & \\
\hline $13: 5$ & $\begin{array}{l}\text { Aparece Cisneros con un } \\
\text { abanico. }\end{array}$ & $\begin{array}{l}\text { Por el material, varillaje de plástico y país de } \\
\text { tela con impresión mecánica, es una } \\
\text { producción industrial de los años } 60 \text { o } 70 \text {. }\end{array}$ \\
\hline $18: 29$ & $\begin{array}{l}\text { Colón muestra a los Reyes una } \\
\text { botella de Cola Cola tras su } \\
\text { regreso de América. }\end{array}$ & $\begin{array}{l}\text { La icónica botella de Coca Cola, con sus } \\
\text { perfiles tan característicos, fue diseñada y } \\
\text { fabricada por la Root Glass Company. La } \\
\text { botella Contour se creó para diferenciarse de } \\
\text { los imitadores, de manera que pudiera ser } \\
\text { reconocible al tacto e incluso rota. El diseño } \\
\text { original fue estilizado para salir al mercado } \\
\text { en } 1916 \text {. En } 1957 \text { empezó a xerografiarse el } \\
\text { logo en la botella. }\end{array}$ \\
\hline 26:39. & Televisión marca ELBE. & $\begin{array}{l}\text { Comercial Radio Bertrán, comenzó en } 1940 \\
\text { como una tienda de electrónica en } \\
\text { Barcelona. Posteriormente pasaría a } \\
\text { denominarse Electrónica Beltrán S.A. (ELBE). } \\
\text { Aunque comenzaron fabricando receptores } \\
\text { de radio, su popularidad llegaría con la } \\
\text { televisión, alcanzando enorme éxito gracias a } \\
\text { sus precios y calidad. En } 1993 \text { fue comprada } \\
\text { por la empresa italiana Seleco, si bien la } \\
\text { marca sigue activa con productor de imagen } \\
\text { y sonido. }\end{array}$ \\
\hline $26: 39$. & $\begin{array}{l}\text { Reproductor de Video, } \\
\text { videocasetes y mando a } \\
\text { distancia. El reproductor } \\
\text { vuelve a aparecer min 28:46. }\end{array}$ & $\begin{array}{l}\text { Marca no identificada. Aunque existieron } \\
\text { antecedentes, la comercialización de los } \\
\text { reproductores de video comenzó en la década } \\
\text { de } 1970 \text { cuando las compañías europeas y } \\
\text { americanas desarrollaron un producto } \\
\text { técnicamente mejor, con contadores de } \\
\text { tiempo más avanzado y videocasetes de } \\
\text { mayor duración. En el caso español comenzó } \\
\text { a convertirse en producto masivo a finales de } \\
\text { los setenta y principio de los ochenta. Para } \\
1980 \text { existían tres estándares técnicos en } \\
\text { competencia, con diferencias y videocasetes } \\
\text { físicamente incompatibles. Betamax, } 2000 \text { y } \\
\text { VHS, quien finamente se hizo con el mercado. } \\
\text { De este sistema son las videocasetes que } \\
\text { aparecen en la película. }\end{array}$ \\
\hline $27: 30$ & $\begin{array}{l}\text { Wilfredo el Roñoso desciende } \\
\text { por el pasamano de una } \\
\text { escalerilla de embarque aéreo } \\
\text { de acoplamiento. }\end{array}$ & \\
\hline
\end{tabular}


Fernández Paradas, A. R., y Sánchez Guzmán, R. La cosmovisión de la Transición española en la película Juana la Loca... de vez en cuando un manual para la comprensión de la comedia histórica de los ochenta

\begin{tabular}{|c|c|c|}
\hline $29: 49$. & $\begin{array}{l}\text { Grupo musical de Felipe El } \\
\text { Hermoso. Instrumentos: } \\
\text { batería, bajo, guitarra eléctrica } \\
\text { y sintetizador. }\end{array}$ & \\
\hline $31: 52$ & $\begin{array}{l}\text { Juana consume un helado } \\
\text { "Polo". }\end{array}$ & $\begin{array}{l}\text { "Polo" es una marca registrada que ha } \\
\text { pasado al lenguaje común. }\end{array}$ \\
\hline $35: 14$ & $\begin{array}{l}\text { La princesa Isabel se sirve una } \\
\text { copa de peppermint. }\end{array}$ & $\begin{array}{l}\text { El peppermint es una bebida alcohólica } \\
\text { elaborada a partir de la menta, de color } \\
\text { verde y muy aromático originario de Francia. } \\
\text { Sola o en combinado con otras, fue un icono } \\
\text { en los años sesenta y setenta. }\end{array}$ \\
\hline $38: 38$ & $\begin{array}{l}\text { Manifestación de médicos: } \\
\text { pancartas y soldados con } \\
\text { mangueras. }\end{array}$ & $\begin{array}{l}\text { Durante los últimos años del franquismo y } \\
\text { durante la Transición fueron muy habituales } \\
\text { las manifestaciones de toda índole, muchas } \\
\text { de ellas acababan siendo disueltas mediante } \\
\text { chorros de agua a presión por la policía. }\end{array}$ \\
\hline 39:55 & $\begin{array}{l}\text { Isabel La Católica se coloca } \\
\text { unas antiparras o gafas de } \\
\text { cerca para leer una carta. }\end{array}$ & \\
\hline $42: 22$ & $\begin{array}{l}\text { Grabadora de voz con } \\
\text { micrófono que recoge las } \\
\text { últimas palabras de Isabel la } \\
\text { Católica. La secuencia evoca el } \\
\text { cuadro "El Testamento de } \\
\text { Isabel la Católica" de Eduardo } \\
\text { Rosales (1864). }\end{array}$ & Marca no identificada. \\
\hline $46: 54$ & Pizarrín y tiza. & \\
\hline $23: 21$ & $\begin{array}{l}\text { Botella de cava, enfriador y } \\
\text { copas. }\end{array}$ & \\
\hline $53: 41$ & $\begin{array}{l}\text { Productos de aseo y belleza } \\
\text { femenina en el camerino de } \\
\text { Zoraida. Envases de plástico. }\end{array}$ & \\
\hline $54: 20$ & $\begin{array}{l}\text { Tarjeta Visa (En el guion, } \\
\text { Diners). }\end{array}$ & $\begin{array}{l}\text { Fue en } 1978 \text { cuando se emitió la primera } \\
\text { tarjeta de crédito en España, si bien la } \\
\text { tarjeta Visa existía ya desde } 1977, \text { las } \\
\text { tarjetas de crédito son de mucho antes. }\end{array}$ \\
\hline $55: 30$ & $\begin{array}{l}\text { Juana con crema en la cara y } \\
\text { los rulos en el cabello. }\end{array}$ & $\begin{array}{l}\text { Más que los objetos en la imagen general del } \\
\text { personaje. }\end{array}$ \\
\hline $1: 00: 28$ & Araña de plástico. & $\begin{array}{l}\text { Aunque la hemos incorporado, en la película } \\
\text { parece tener intención de realidad. }\end{array}$ \\
\hline 1:04:50. & $\begin{array}{l}\text { Juana lanza dardos sobre } \\
\text { Zoraida. }\end{array}$ & $\begin{array}{l}\text { Los dardos son un juego que se practica } \\
\text { individualmente o por equipos, y que } \\
\text { consiste en lanzar tres dardos } \\
\text { alternativamente cada jugador a una diana } \\
\text { hasta completar una puntuación determinada } \\
\text { o alcanzar unos sectores determinados. } \\
\text { Aunque nos hay de otros materiales, lo que } \\
\text { aparecen en la película son de plástico, } \\
\text { apropiados para dianas electrónicas }\end{array}$ \\
\hline 1:08:15. & $\begin{array}{l}\text { Príncipe Juan niño en un } \\
\text { andador. }\end{array}$ & $\begin{array}{l}\text { Aunque los andadores son mucho más } \\
\text { antiguos, lo incorporamos en las } \\
\text { descontextualizaciones por su fabricación en } \\
\text { aluminio y plástico. }\end{array}$ \\
\hline $1: 10: 47$ & $\begin{array}{l}\text { Megáfono de mano portado } \\
\text { por Torquemada, mientras }\end{array}$ & \\
\hline
\end{tabular}


Fernández Paradas, A. R., y Sánchez Guzmán, R. La cosmovisión de la Transición española en la película Juana la Loca... de vez en cuando un manual para la comprensión de la comedia histórica de los ochenta

\begin{tabular}{|c|c|c|}
\hline & $\begin{array}{l}\text { marca el juego en el partido } \\
\text { de tenis. }\end{array}$ & \\
\hline $1: 10: 55$ & $\begin{array}{l}\text { Vestuario del Rey Felipe y } \\
\text { Duque de Medina Sidonia, } \\
\text { camiseta polo de tenis Adidas. }\end{array}$ & $\begin{array}{l}\text { Marca ropa deportiva alemana creada en } \\
1949 . \text { El logotipo que aparece en las } \\
\text { prendas, el trébol de tres hojas fue usado } \\
\text { hasta } 1997 .\end{array}$ \\
\hline $1: 10: 55$ & $\begin{array}{l}\text { Vestuario del Rey Felipe y } \\
\text { Duque de Medina Sidonia, } \\
\text { deportivas de tenis. }\end{array}$ & \\
\hline $1: 10: 55$ & Silla de juez de tenis. & \\
\hline $1: 11: 13$ & $\begin{array}{l}\text { Torquemada ofrece al Rey } \\
\text { sendas botellas de Coca Cola y } \\
\text { Mirinda (En el guion Fanta). }\end{array}$ & $\begin{array}{l}\text { La popular marca Mirinda de refrescos tiene } \\
\text { su origen en España en } 1959 \text { y significa } \\
\text { "admirable, maravillosa" en esperanto. Junto } \\
\text { a Kas fue la marca de refrescos autóctona de } \\
\text { mayor popularidad. En } 1970 \text { fue comprada } \\
\text { por la multinacional Pepsi. }\end{array}$ \\
\hline $1: 12: 12$ & Cigarrillo industrial. & $\begin{array}{l}\text { El tabaco fue introducido en Europa por el } \\
\text { embajador francés Jean Nicot, a través de } \\
\text { Lisboa hacia } 1560 \text { a partir de una planta } \\
\text { traída desde florida. Los primeros cigarrillos } \\
\text { de papel manufacturados y empaquetados } \\
\text { empezaron a llegar a España, desde América, } \\
\text { entre } 1825 \text { y } 1833, \text { extendiéndose a } \\
\text { posteriori por Europa. }\end{array}$ \\
\hline $1: 13: 02$ & $\begin{array}{l}\text { Póster y camisetas del rey } \\
\text { difunto. }\end{array}$ & \\
\hline $1: 19: 55$ & Altavoz eléctrico. & \\
\hline $1: 20: 34$ & Cartucho de dinamita. TNT. & $\begin{array}{l}\text { El trinitrotolueno (TNT), compuesto químico } \\
\text { explosivo. }\end{array}$ \\
\hline
\end{tabular}

Fuente: Elaboración propia.

\subsection{El guion de la película, historias que no fueron contadas}

De todos modos, de lo escrito por Alonso Millán en el guion, a lo que se vio en la pantalla hubo sustanciales cambios ${ }^{3}$. Muchos chistes se quedaron sin ver por los espectadores, algunas escenas aunque se rodaron nunca se montaron (gabinete de envenenadora de Juana la Loca, entrevista de Torquemada con el trasunto del Ministro Miguel Boyer, Fray Bollero (Manuel de Blas, desaparecido en la película definitiva), a costa de los seguros sociales de los mismos, entre otros), se añadieron secuencias nuevas (sueño de Juana), o las propias canciones, cuyas letras no están en él, y otras referencias a la política contemporáneas fueron eliminadas. Sería prolijo enumerar todos estos cambios, y tampoco es el objetivo del artículo, pues es nuestro fin centrarnos en película terminada, pero queremos destacar aquellos personajes contemporáneos de los primeros ochenta, que se quedaron sin ser mencionados finalmente (Benet Ferrando, 2012).

${ }^{3}$ Biblioteca y archivo de la Filmoteca Nacional (Madrid): Guion: Juana la Loca... de vez en cuando. G1916. 
Fernández Paradas, A. R., y Sánchez Guzmán, R. La cosmovisión de la Transición española en la película Juana la Loca... de vez en cuando un manual para la comprensión de la comedia histórica de los ochenta

Tabla 3

\begin{tabular}{|c|c|c|}
\hline $\begin{array}{l}\text { Página } 12 \text { del } \\
\text { guion. }\end{array}$ & $\begin{array}{l}\text { Princesa Isabel: "Y vosotros sois } \\
\text { ácratas y masones de toda la } \\
\text { vida, como Fernández Ordoñez. }\end{array}$ & $\begin{array}{l}\text { Francisco Fernández Ordóñez (1930- } \\
\text { 1992): político español de la UCD y del } \\
\text { PSOE, ostentó las carteras de Hacienda } \\
\text { (1977-1979) y Justicia (1980-1981) } \\
\text { durante los gobiernos del Adolfo Suárez, } \\
\text { y Asuntos Exteriores (1985-1992) ya en } \\
\text { el gobierno de Felipe González. }\end{array}$ \\
\hline Página 18 & $\begin{array}{l}\text { Isabel la Católica (a su hija } \\
\text { Juana): "Holding, mucho holding, } \\
\text { empezando por el Opus y } \\
\text { terminando por las Torres de } \\
\text { Colón, podemos ofrecer a } \\
\text { Verstrynge en el mismo lote y así } \\
\text { nos lo quitamos de encima". }\end{array}$ & $\begin{array}{l}\text { Jorge Verstrynge (1948- ): nacido en } \\
\text { Tánger y con nacionalidad franco- } \\
\text { española, entre } 1979 \text { y } 1986 \text { fue } \\
\text { secretario general de Alianza Popular, } \\
\text { partido fundado por Manuel Fraga, } \\
\text { que, tras su disolución en 1989, } \\
\text { devendría en el actual Partido Popular. } \\
\text { Tras su enfrentamiento con el } \\
\text { fundador de Alianza Popular evolucionó } \\
\text { hacia posturas más de izquierda, } \\
\text { ingresando en el PSOE en } 1993 \\
\text { (partido que abandonó) y siendo } \\
\text { posteriormente asesor de Izquierda } \\
\text { Unida. En la actualidad es profesor } \\
\text { titular de la Facultad de Ciencias } \\
\text { Políticas y Sociología de la Universidad } \\
\text { Complutense de Madrid. }\end{array}$ \\
\hline Página 19 & $\begin{array}{l}\text { Juana la Loca: "No me importa el } \\
\text { físico, me decís a Julio Feo y me } \\
\text { lo quedo". } \\
\text { Isabel la Católica: "Está también } \\
\text { en Italia el Conde Landelino Fino, } \\
\text { sobrino del Papa Lamban II". }\end{array}$ & $\begin{array}{l}\text { Julio Feo (1936- ): político español del } \\
\text { PSOE. Tras las elecciones de 1982, } \\
\text { ostentó el cargo de subsecretario } \\
\text { (1982-1986) y secretario general de la } \\
\text { Presidencia del Gobierno (1986-1987). } \\
\text { Landelino Lavilla (1934- ): político } \\
\text { español perteneciente a la UCD. Ente } \\
\text { otros cargos, fue Ministro de Justicia } \\
\text { durante los gobiernos de Adolfo Suárez } \\
\text { y presidente del Congreso de los } \\
\text { Diputados entre } 1979 \text { y 1982, siendo el } \\
\text { presidente de la cámara durante el } \\
\text { Golpe de Estado de } 1981 \text {. }\end{array}$ \\
\hline Página 26 & $\begin{array}{l}\text { Cisneros: "Podemos organizar } \\
\text { expediciones para convertir a } \\
\text { nuestra religión a los infieles... el } \\
\text { padre Bartolomé de las Casas } \\
\text { podría". } \\
\text { Fernando el Católico: "¿Por qué } \\
\text { no se casa con Paloma Gómez } \\
\text { Borrero y nos deja tranquilos?" }\end{array}$ & $\begin{array}{l}\text { Paloma Gómez Borrero (1934-2017): } \\
\text { periodista y escritora, conocida } \\
\text { popularmente, por sus crónicas } \\
\text { vaticanas en distintos medios de } \\
\text { comunicación españoles. }\end{array}$ \\
\hline Página 87 & $\begin{array}{l}\text { Juana la Loca: "Hablar con Julio } \\
\text { Feo que invente eso del cambio". }\end{array}$ & Nueva alusión a Julio Feo. \\
\hline Página 87 & $\begin{array}{l}\text { Juana hace una referencia a José } \\
\text { Luis Núñez para conseguir el } \\
\text { "Camino del Mediterráneo". }\end{array}$ & $\begin{array}{l}\text { José Luis Núñez (1931- ): además de } \\
\text { destacado empresario de la } \\
\text { construcción, es conocido como el } \\
\text { presidente del Futbol Club Barcelona } \\
\text { que más años estuvo en el cargo, } \\
\text { entre } 1978 \text { y 2000, siendo además el } \\
\text { que más títulos consiguió. }\end{array}$ \\
\hline
\end{tabular}


Fernández Paradas, A. R., y Sánchez Guzmán, R. La cosmovisión de la Transición española en la película Juana la Loca... de vez en cuando un manual para la comprensión de la comedia histórica de los ochenta

\begin{tabular}{|l|l|l|}
\hline Página 89 & $\begin{array}{l}\text { Habla Torquemada con intención } \\
\text { de matar al Rey: "Y no olvidemos } \\
\text { que es extranjero como } \\
\text { Verstrynge". }\end{array}$ & Nueva alusión a Jorge Verstrynge. \\
\hline Página 98 & $\begin{array}{l}\text { Torquemada: "Si os parece } \\
\text { Majestad cuando la hayamos } \\
\text { rotos todos los huesos podemos } \\
\text { acusarla de ser una de "Las } \\
\text { Vulpes"'". }\end{array}$ & $\begin{array}{l}\text { Las Vulpes, fue una banda de rock } \\
\text { femenina de Bilbao formada en } 1982 . \\
\text { Se hicieron famosas al interpretar el } 16 \\
\text { de abril de 1983 en el programa de } \\
\text { TVE española Caja de Ritmos (en } \\
\text { horario familiar) su canción Me Gusta } \\
\text { ser una zorra, lo que ocasiono una } \\
\text { encendida polémica, dimitiendo el } \\
\text { director del programa, Carlos Tena y } \\
\text { disolviéndose el grupo musical, tras } \\
\text { imponer una querella por supuesto } \\
\text { escándalo público la Fiscalía General } \\
\text { del Estado. }\end{array}$ \\
\hline
\end{tabular}

Fuente: Elaboración propia.

\section{CONCLUSIONES}

El análisis realizado, nos ha permitido comprobar que todas y cada una de las críticas realizadas a la película durante su estreno y exhibición, ciertamente, en lo que respecta al guion, vienen a coincidir con la realidad. Ahora bien, con la perspectiva de tiempo que dan los 35 años que han pasado desde el estreno de la película, lo que para otros fue una tragedia cinematográfica, para nosotros se ha convertido en una fuente histórica imprescindible para comprender un periodo fundamente de nuestra historia reciente. Juan la Loca... de vez en cuando, supone una obra maestra desde el punto de vista histórico, ya que su guionista, Juan José Alonso Millán, fue capaz de concentrar en los 77 minutos que dura la película la cosmovisión sobre su propio mundo, en una amplia vertiente cultural, política, ideológica, judicial, legislativa, social, artística, mecánica, tecnológica, etc.

La película presenta multitud de códigos audiovisuales, expresivos y comunicativos, que hacen que en la actualidad sea imposible su compresión por aquellos que no vivieron la época de la realización de la película. El análisis aquí realizado, supone aportar un pequeño manual de compresión de la historia de la Transición española.

Sí los críticos de la época ya pusieron de manifiesto los contenidos políticos, sociales o legislativos de la película, nosotros hemos registrado hasta 61 referencias a multitud de hechos diferenciados, de diversa naturaleza. La contextualización de los mismos, nos ha permitido expandir el universo de Juana la Loca... de vez cuando, hasta unos límites insospechados hasta el momento.

En la tabla dos, hemos referenciado hasta 27 objetos, repartidos en los 77 minutos que dura la película, de diversa índole, objetos tecnológicos para reproducir video o música; botellas y bebidas de la época; alusiones a prensa y revista, etc. Todos ellos esconden una historia y expanden el universo de Juana la Loca. 
Fernández Paradas, A. R., y Sánchez Guzmán, R. La cosmovisión de la Transición española en la película Juana la Loca... de vez en cuando un manual para la comprensión de la comedia histórica de los ochenta

Sí la gran cantidad de información que nos ha ofrecido el análisis de la película, nos ha permitido aproximarnos a la misma como una fuente de información privilegiada y como un excepcional documento histórico, la posibilidad de analizar el guion original y poder compararlo con la película final, nos ha permitido tomar conciencia de los cambios producidos entre uno y otra, ya que en origen, había multitud de escenas que estaban previstas y que finalmente no llegaron a incluirse. Hemos detectado hasta 8 omisiones diferentes que aparecían en el guion y que finalmente no fueron incluidas en la película. Estas omisiones, en su mayoría eran relativas a personalidades políticas de la época, pero también a periodistas y músicos. Creemos que es importante recuperar la presencia de estos nombres, que de haber aparecido en la película habrían enriquecido, aún más, el documento histórico objeto de estudio.

\section{REFERENCIAS}

Benet Ferrando, V. J. (2012). El cine español: Una historia cultural. Barcelona: Paidós.

Dirección General de Cinematografía. Cine Español, 1983. Madrid: Ministerio de Cultura 1983.

Del Amo, Á. (2009). La comedía cinematográfica española. Madrid: Alianza Editorial, 2009.

García Barrientos, J. L. (2004). Teatro y Ficción. Madrid: Editorial Fundamentos.

González González, L. M. (2009). Fascismo, "kitsch" y cine histórico español (19391953). Cuenca: Ediciones de la Universidad de Castilla-La Mancha.

Guerra Gómez, A. (2012). El rostro amable de la represión. Comedia popular y "landismo" como imaginarios en el cine tardofranquista. Hispania Nova: Revista de historia contemporánea, 10.

Huerta Floriano, M. Á., \& Pérez Morán, E. (2015). De la comedia popular tardofranquista a la comedia urbana de la transición: Tradición y modernidad. Historia Actual Online, 37, 201-212.

López Gandía, J., \& Pedraza, P. (1989). El rey de Burlas: la risa en la comedia española de los '80. En Escritos sobre el cine español: 1973-1987, 133-148. Valencia: Institut Valencià d'Arts Escéniques, Cinematografia i Música, Filmoteca de la Generalitat Valenciana.

Losilla Alcalde, C. (1999). Tan lejos, tan cerca: La representación de la historia y la historia como representación en el cine español de los años ochenta y noventa. Cuadernos de la Academia, 6, 117-126. 
Fernández Paradas, A. R., y Sánchez Guzmán, R. La cosmovisión de la Transición española en la película Juana la Loca... de vez en cuando un manual para la comprensión de la comedia histórica de los ochenta

Martínez Montalbán, J. L. (1989). Cine. En Doce años de cultura española (19761987). Madrid: Ediciones Encuentro.

Monterde, J. E. (1993). Veinte años de cine español (1973-1992): Un cine bajo la paradoja. Madrid: Paidós.

Montoya, A.; Ponga, P.; Salvans, R., \& Torreiro, M. (2015). Especial comedia española, el eterno filón de la comedia. Fotogramas \& DVD: la primera revista de cine 2060, 86-98.

Payán, M. J. (2007). La historia de España a través del cine. Madrid: Cacitel.

Pérez Gómez, Á. A.; \& Equipo Reseña (1984). Cine para Leer, 1983: Historia crítica de un año de cine. Bilbao: Editorial Mensajero.

Torres, A. M. (1992). Gracias y desgracias del cine español de los ochenta. Claves de razón práctica, 22, 64-68.

Utrera Macías, R. (2005). El concepto de cine nacional: Hacia otra historia del cine español. Comunicación: Revista Internacional de Comunicación Audiovisual, Publicidad y Estudios Culturales, 3, 83-100.

Vidales Gonzáles, C. E. (2009). La relación entre la semiótica y los estudios de la comunicación; un diálogo por construir. Comunicación y sociedad, 11.

Zunzunegui, S. (2002). Historias de España. De qué hablamos cuando hablamos de cine español. Valencia: Ediciones de la Filmoteca.

Zunzunegui, S. (2005). Los felices sesenta: Aventuras y desventuras del cine español (1959-1971). Barcelona: Paidós.

\section{AUTORES:}

\section{Antonio Rafael Fernández Paradas}

Doctor en Historia del Arte por la Universidad de Málaga, con la tesis doctoral titulada Historiografía y metodologías de la historia del mueble en España (18722011). Un estado de la cuestión. Graduado en Historia del Arte y licenciado en Documentación por la Universidad de Granada. Máster en Peritaje y Tasación de Antigüedades y obras de arte por la Universidad de Alcalá de Henares. Actualmente es profesor ayudante doctor de la Universidad de Granada, donde imparte docencia en el departamento de Didáctica de las Ciencias Sociales de la Facultad de Ciencias de la Educación, y docente del máster Arte y Publicidad de la Universidad de Vigo. antonioparadas@ugr.es

\section{Rubén Sánchez Guzmán}

Licenciado en Historia del Arte por la Universidad Autónoma de Madrid. En la actualidad ejerce como profesor de Historia del Arte y Conocer Madrid en los Centros 
Fernández Paradas, A. R., y Sánchez Guzmán, R. La cosmovisión de la Transición española en la película Juana la Loca... de vez en cuando un manual para la comprensión de la comedia histórica de los ochenta

Culturales del Ayuntamiento de Madrid (Educo-Actividades). Ha sido docente del I máster en Escultura Barroca Española. Desde los Siglos de Oro a la Sociedad de la Información y las Redes Sociales, impartido por la Universidad Internacional de Andalucía. Perito tasador en antigüedades y obras de arte en el departamento de arte y sala de subastas Lamas Bolaño de Madrid, realizando funciones de tasación, catalogación y asesoramiento personalizado.

ruben sanguzman@hotmail.com 